\title{
Can restored forests retrieve the flora of potential natural forests in urban areas? Comparison in 100, 500 and 45 -year-old planted forests
}

\begin{abstract}
Fujiwara, K.: Can restored forests retrieve the flora of potential natural forests in urban areas? Comparison in 100, 500 and 45-year-old planted forests. — Fl. Medit. 31 (Special Issue): 371 406. 2021. - ISSN: 1120-4052 printed, 2240-4538 online.

There are three big restored forest areas in Tokyo and Yokohama. These were planted using the main trees of the natural forest for landscaping in Meguro (Tokyo), for restoring natural forest following succession in Shinjuku (Tokyo), and by planting saplings for developing natural forest directly in Yokohama. The biggest area is around the Meiji Jingu Shinto Shrine, which was constructed in 19151920 with a designed pine plantation and trees from the flora of selected natural forests, donated from throughout the whole Japanese Archipelago. Now this forest has developed into a semi-natural forest with landscaping trees and successional forests. The second large forest is around the Institute for Nature Study of the National Museum of Nature and Science in Meguro (Tokyo). It began as a lord's residence during the Kamakura Era, and the grounds became an Imperial estate from 1917. Since then the natural environment has been conserved. It was mostly a Japanese Garden, with old Castanopsis cuspidata var. sieboldii forest on the embankment (believed to have been built during the Muromachi period) and secondary forests. Tall, well-shaped pines (Pinus thunbergii), C. cuspidata var. sieboldii and Quercus acuta with 17 other species (totally 575 trees) were transported from here to the Meiji Jingu Shrine for its construction. Since 1947 the Institute for Nature Study belongs to the Ministry of Education, which opened it to the public. The third large forest is on the Tokiwadai Campus of Yokohama National University (YNU). This site was originally the third-oldest country-club golf course in the Kanto region. The oldest forest, a forest of Castanopsis cuspidata var. sieboldii, was planted on one part of the golf course in 1922. In 1976 and 1979, when all faculties of YNU moved to Tokiwadai, YNU planted saplings of species from the natural forest. Each of these sites developed increasingly natural forests, and many forest species came back. The forests with Castanopsis canopies, i.e. Meiji Jingu Shrine and Institute for Nature Study, have next-generation species on the forest floor. Unfortunately, in the forest of Yokohama National University, the main species planted were Cinnamomum camphora, Quercus glauca, Machilus thunbergii, and Q. myrsinaefolia.; later, a small amount of Castanopsis cuspidata var. sieboldii was planted. The oldest forest, a relic of the former golf-course period, had a canopy of $C$. cuspidata var. sieboldini, has successors in the forest, and formed a multi-layered forest despite its short history. For the restoration of natural forests, canopy and subcanopy species, plus some shrub species, from natural forests will become the key species. Otherwise there are no sources of seeds to be distributed in urban areas, and restoration of the species richness will take time.
\end{abstract}

Key words: dense mixed native-species plantation, evergreen broad-leaved forest, key forestrestoration species, Meiji Jingu Shrine, restoration of natural forest, urban forest. 


\section{Introduction}

There are several methods for restoring natural forests: following succession, landscaping plantation, and plantation of saplings of canopy species from natural forest (mixed and densely: 1-3 individuals $/ \mathrm{m}^{2}$ ). Each method may use natural-forest species for plantation. This paper compares changes and development of native species based on potential natural forest within three Japanese examples. One is the roughly 100-year-old forest of the Meiji Jingu Shinto Shrine. The second example, from the Kamakura Era, is a landscaping plantation as a Japanese Garden of the so-called Shirokane (millionaire), which was afterward used by The Institute for Nature Study of the National Museum of Nature and Science, after having served as a samurai residence (Edo Era: 1964-1868), for navy and army powder storage (Meiji Era: 1872-1913), and as an imperial property (Taisho-Showa Era: 19171947) (Figs. 1, 2).



Fig. 1. Location of the Meiji-Jingu (Shito Shrine) and the Institute for Nature Study in Tokyo. 


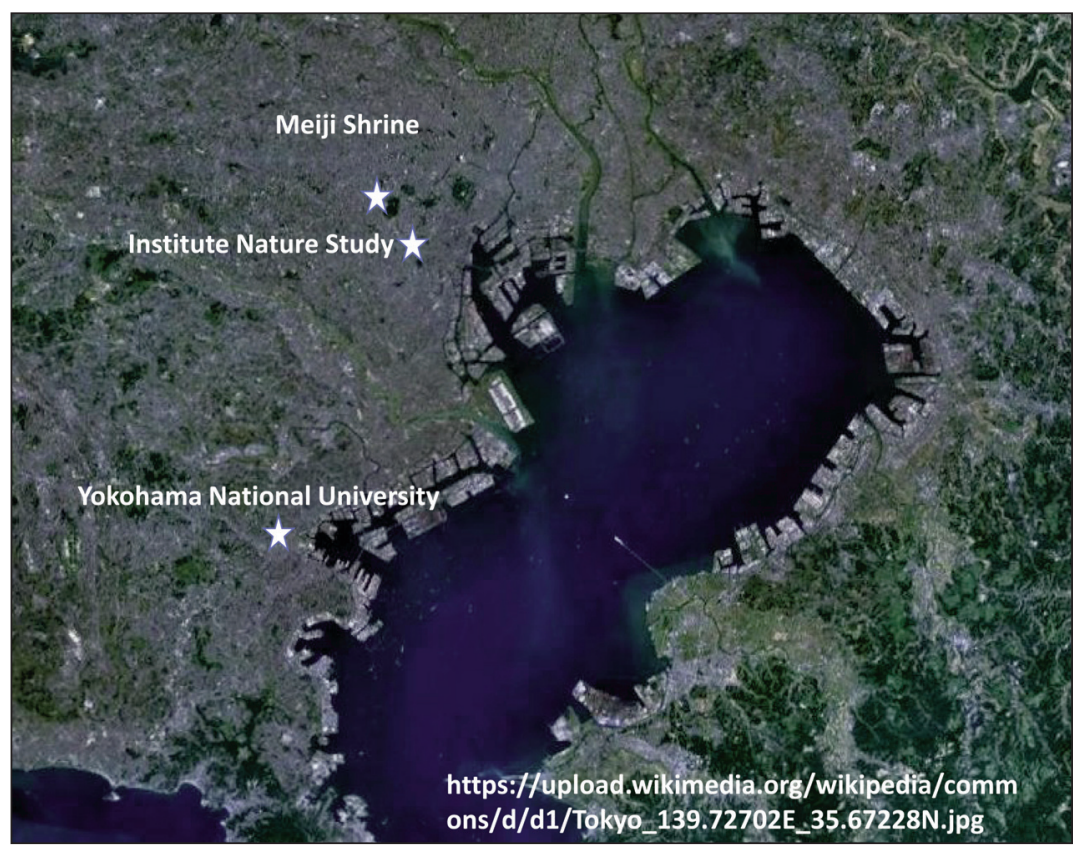

Fig. 2. Location of Meiji-Jingu, the Institute for Nature Study, and Yokohama National University in the Kanto region.

The area of the Meiji Shinto Shrine, including the forest, is 70 ha and was begun in 1915 (a six-year project) for dedication to the deified spirits of Emperor Meiji and his wife, Empress Shoken. It is located in Shibuya (Tokyo: Fig. 3). The forest of Meiji Jingu Shrine was designed to follow succession over the next 100 years.

The Institute for Nature Study of the National Museum of Nature and Science has 20ha and had its beginnings as a lord's residence during the Kamakura Era. The grounds became an Imperial estate from 1917, and since then the natural environment has been conserved. Now it belongs to the Ministry of Education, which opened it to the public. The forest was designed as a landscaping area and afterword developed several types of forests (Fig. 4). It even donated 475 black pines (Pinus thunbergii) for landscaping and several Castanopsis cuspidata var. sieboldii trees with tall, good shapes for planting at the Meiji Shinto Shrine. Individuals of Castanopsis cuspidata var. sieboldii on the embankments in the Institute for Nature Study are told to be 400 years old (Okuda 1972).

The third forest includes various tracts on the Tokiwadai Campus of Yokohama National University (45 ha) in Yokohama City (Fig. 5). This area was the third-oldest golf course (Hodogaya Country Club) in Kanto, built in 1923. Then Yokohama National University bought the land as a place to unify its various university faculties. The environmental protection forests (restoration of natural forest by Miyawaki method) were done in 1976 and 1979, and there are also relicts of the landscaping forests from 1923. 


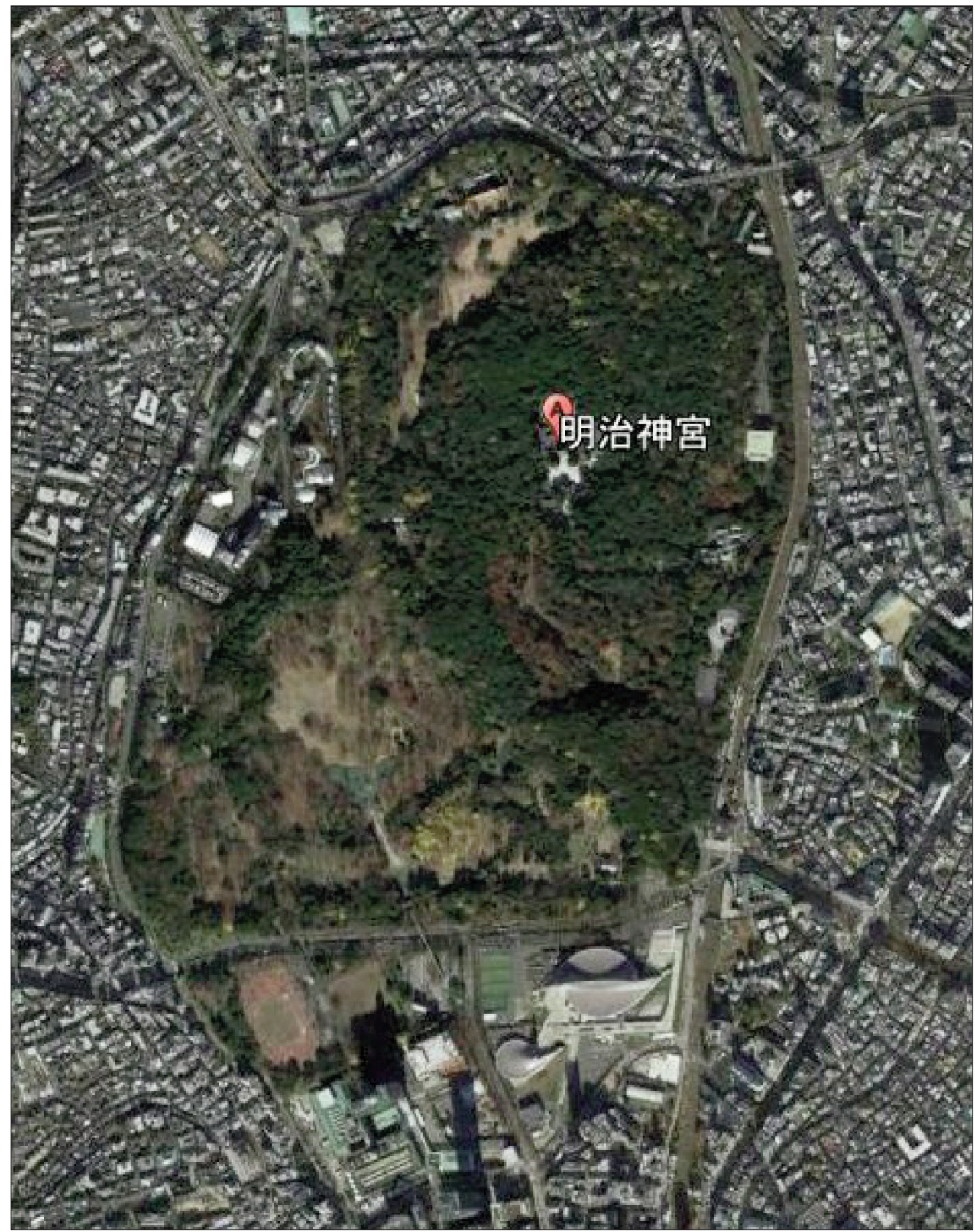

Fig. 3. Meiji-Jingu Shrine on Google Earth (photo on Dec. 16, 2020). 


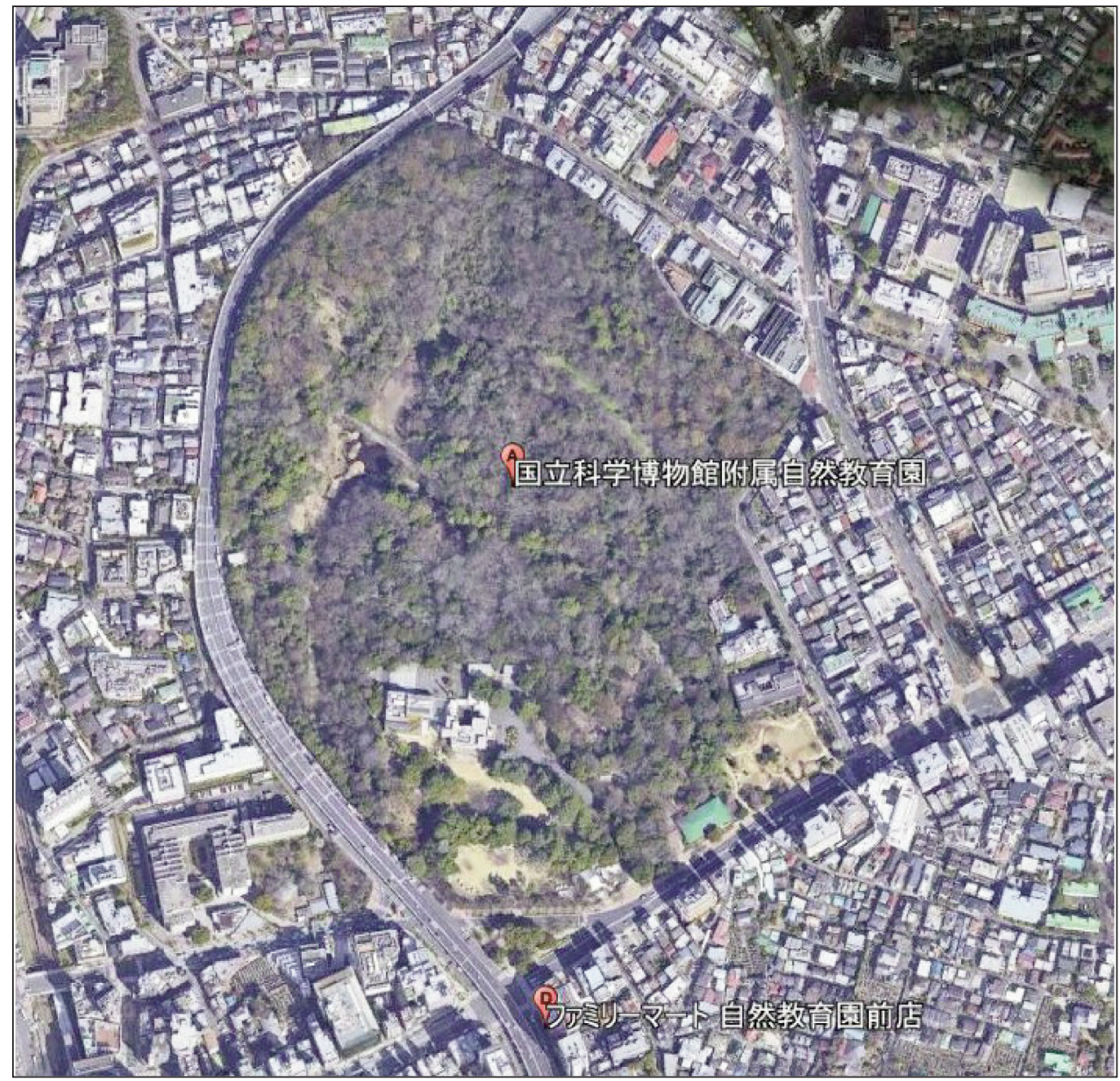

Fig. 4. Institute for Nature Study on Google Earth (photo on March 13, 2019).

\section{History of plantation and developments:}

\section{The Meiji Shinto Shrine}

The forest around the Meiji Jingu Shrine was designed to be a plantation of 100,000 trees dedicated from all over Japan. The species with the most individuals planted, in decreasing order, were 1. Ilex crenata, 2. Pinus thunbergii, 3. Cinnamomum camphora, 4. Cleyera japonica, 5. evergreen Quercus spp, 6. Chamaecyparis obtusa, 7. Eurya japosica, 8. Pinus densiflora, 9. Cryptomeria japonica, 10. Rhododendoron spp., 11. Castanopsis cuspidata var. sieboldii, 12. Chamaecyparis picifera and 13. Zelkova serrata, etc. (Table 1). Dr. Takanori Hongo (forester) designed the plantation to have coniferous species, especially Pinus spp. in the canopy (12-24 m height), with Cryptomeria japonica, Chamaecyparis spp. and 


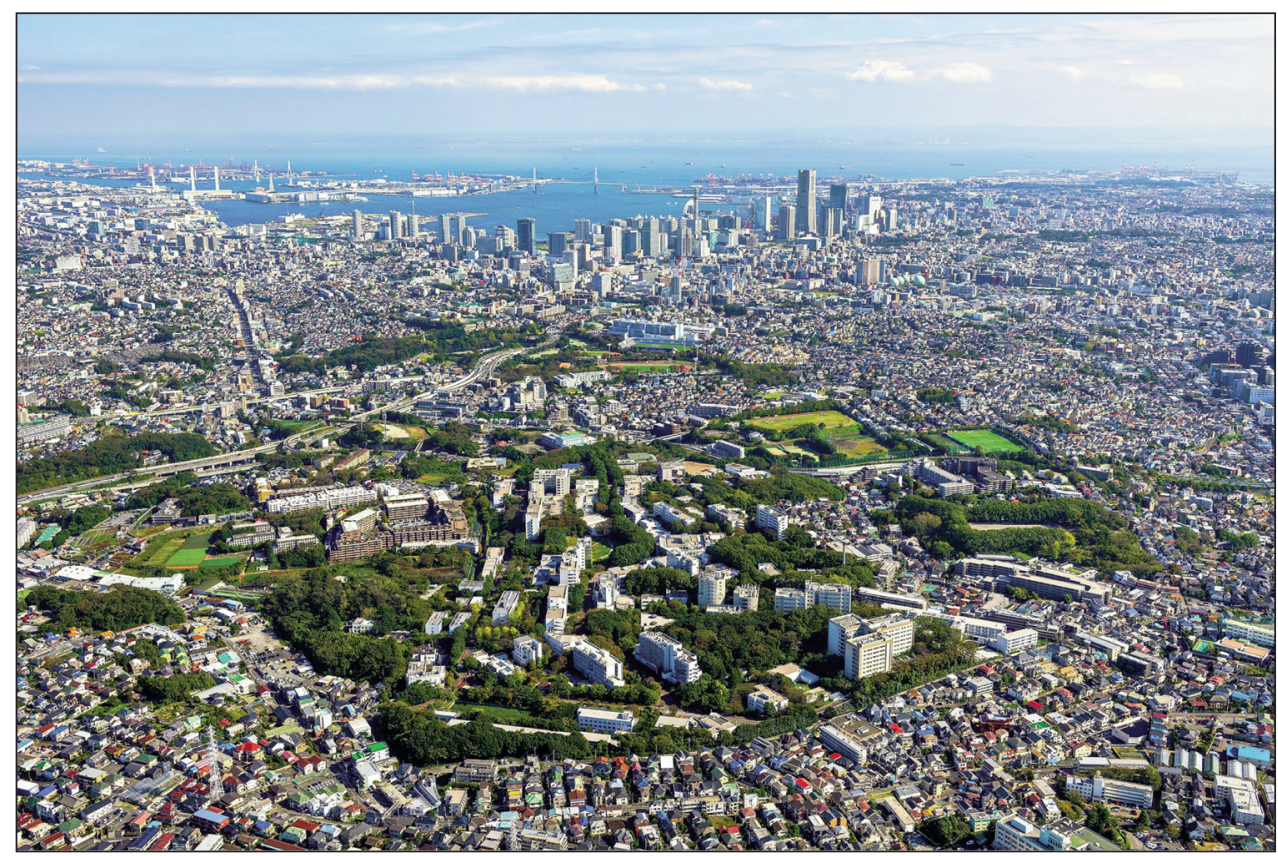

Fig. 5. Aerial photo of Yokohama National University (photo by Yokohama National University).

Abies firma in a sub-canopy layer (7-9 m). Then he put evergreen broad-leaved trees under the conifers to grow to a climax forest after succession (4-6 m). The fourth component is shrubs (Fig. 6 in Hongo 1923) (Ueda 2009). Pines already remained in the Forest Garden area, as well as Cryptomeria and Chamaecyparis spp. These species had good shapes for landscaping, and they were suitable for making a temporary canopy quickly. Evergreen broad-leaved trees, as the third layer, were ideal forest tree species and promised a good scenic effect.

The construction was begun in March 1915, with construction of the various precincts planned to be finished within six years.

An embankment was built on surrounding areas, but huge trees remained in this area, including Aphananthe aspera and Zelkova serrata (Ulmaceae). Outer masonry was built in the surroundings and piled up to avoid existing trees of $Z$. serrata and $A$. aspera, which totaled 35 individuals with more than one meter of circumference.

The length of the embankment is $3316 \mathrm{~m}$, and shrubby Ilex crenata was planted by donation of 10,000 individuals. The back-forest area of the shrine had filled soil, and evergreen broad-leaved species were planted for fire prevention and protection against smoke. The evergreen broad-leaved species were Cleyera japonica, Quercus myrsinaefolia, Castanopsis cuspidata var. sieboldii, Cinnamomum camphora, Ilex integra, Osmanthus fragrans and Michelia compressa (Hongo 1923). This area is a main part of the current Cinnamomum camphora-Castanopsis cuspidata var. sieboldii community. Maintenance after plantation was to prohibit collection of dropped leaves 
and for weeding. Cleaning of dropped leaves should be limited to the surroundings of buildings, on roads, in the garden, but not in the forests. Cleaning and weeding in the forest cause a decline in soil fertility and lead to forest devastation. When weeds grow over saplings, weeding is necessary several years after forestation.

Hongo (1923) also described details of 1) protection against storms, rain and snow, human hazards, damage to trees and smoke damage, against forest garden; 2) maintenance of garden roads, ponds, streams, etc.; 3) future measures for donated trees. Later Uehara (1971) described the entire planning and process of reforestation of the Meiji Jingu Shrine forest.

Table 1. Number of trees newly planted at the time of construction (more than 500 trees). (Meiji Jingu Building Document 1928).

\begin{tabular}{|c|c|c|}
\hline Life form & Plant name & Numbers* \\
\hline \multirow{9}{*}{ Conifers } & Pinus thunbergii & 12.317 \\
\hline & Chamaecyparis obtusa & 6.243 \\
\hline & Pinus densiflora & 4,054 \\
\hline & Cryptomeria japonica & 3.938 \\
\hline & Chamaecyparis picifera & 2.413 \\
\hline & Abies firma & 1.493 \\
\hline & Taxus cuspidata & 956 \\
\hline & Podocarpus nagi & 619 \\
\hline & Platycladus orientalis & 505 \\
\hline \multirow{11}{*}{ Evergreen broad-leaf trees } & Ilex crenata & 21.783 \\
\hline & Cinnamomum camphora & 8.957 \\
\hline & Cleyera japonica & 7.886 \\
\hline & Evergreen Quercus spp. & 6,666 \\
\hline & Eurya japonica & 5.989 \\
\hline & Rhododendron spp. & 3.732 \\
\hline & Castanopsis cuspidata var. sieboldii & 2.571 \\
\hline & Camellia sasanqua & 1.623 \\
\hline & Camellia japonica & 1.028 \\
\hline & Ilex integra & 554 \\
\hline & Ternstroemia gymnanthera & 531 \\
\hline \multirow{4}{*}{ Deciduous broad-leaf trees } & Zelkova serrata & 2.242 \\
\hline & Acer spp. & 747 \\
\hline & Prunus spp. & 707 \\
\hline & Ginkgo biloba & 639 \\
\hline Herbs & Cymbidium goeringii & 10.000 \\
\hline
\end{tabular}






Fig. 6. Order of transition from establishment of the forest garden to the final (expected) appearance of the forest face (redrawn from Hongo 1923). 


\section{The Institute for Nature Study of the National Museum of Nature and Science}

The Institute for Nature Study is located in Shirokanedai, a region of Tokyo that was created by marine erosion during a diluvial epoch some 200,000 to 500,000 years ago. In the Heian period (794-1185), it is thought that rice paddies were cultivated in the swampy lowlands of the Meguro and Shibuya Rivers, while gromwell, an essential ingredient in dyemaking, was grown in the broad plains above. With the start of the Muromachi period (1336-1573), the powerful clans of this area built residences here; earthen walls found in Shirokanedai are believed to be the remains of these houses. Though the masters of these houses are unknown, the place name "Shirokanedai" first appears in records dated to 1559 , and one Shinrokuro, a grandson of military commander Ota Dokan (1432-1486), is listed as the area's governor in period records. Moreover, legend has it that Shinrokuro was "rich in silver" (shirokane-choja). In the Edo period, Shirokanedai came under the control of Zojoji, a Buddhist temple. In 1664, it became the villa of Matsudaira Sanukinokami Yorishige (1622-1695), lord of Takamatsu and elder brother of the shogun Tokugawa Mitsukuni (1628-1701). Some of the older, larger pines in the Institute for Nature Study's modern gardens are thought to have been among the very trees that grew in Matsudaira's garden. In the Meiji period (1868-1912), the site was used as a gunpowder magazine, under the control of the Naval Ministry and Army Ministry. It was taken over by the Imperial Family Forests and Fields Bureau of the Imperial Household Ministry in 1917, whereupon it was renamed the Shirokane Imperial Estate (Fig. 4). http://www.ins.kahaku.go.jp/english/about/history/index.html

Uehara (1971) made a tree survey at the Institute for Nature Study before 1954 and decided to move 575 trees of 19 species from the Institute to Meiji Jingu Shrine. Pinus thunbergii had 475 individuals of large and small scenic trees. Conifer and evergreen broad-leaved trees, plus deciduous Acer palmatum, were 462 individuals. Transplantation and transportation work was carried out after two years of protective care (digging around the roots to foster the development of fibrous roots) before planting to the new site. This was carried out by over 1000 people for about a year (Uchida 1992).

The site passed to the Ministry of Education in 1949, whereupon it was designated a "national monument and historical landmark" and opened to the public as a national natural-education park (Fig. 4). It obtained its current status as the Institute for Nature Study of the National Museum of Nature and Science in 1962. http://www.ins.kahaku.go.jp/english/about/history/index.html

\section{Yokohama National University}

The Tokiwadai Campus of Yokohama National University (YNU) is located in the middle of Yokohama City (Fig. 5). Most of the forests were relicts of plantations from the previous golf course (Fig. 7), environmental protection forest which is origin of densely planted saplings (one to 1.5 saplings per square meter) (Fig. 8) and landscaping plantation. The golf course was named Hodogaya Country Club, was inaugurated in 1922, and was the third-oldest golf course in the Kanto region. Hodogaya Country Club moved to Asahi-ku (1967) in Yokohama after the Yokohama National University required the integrated land, and construction began in 1968. Therefore, relicts of forests were already 45 years old. 


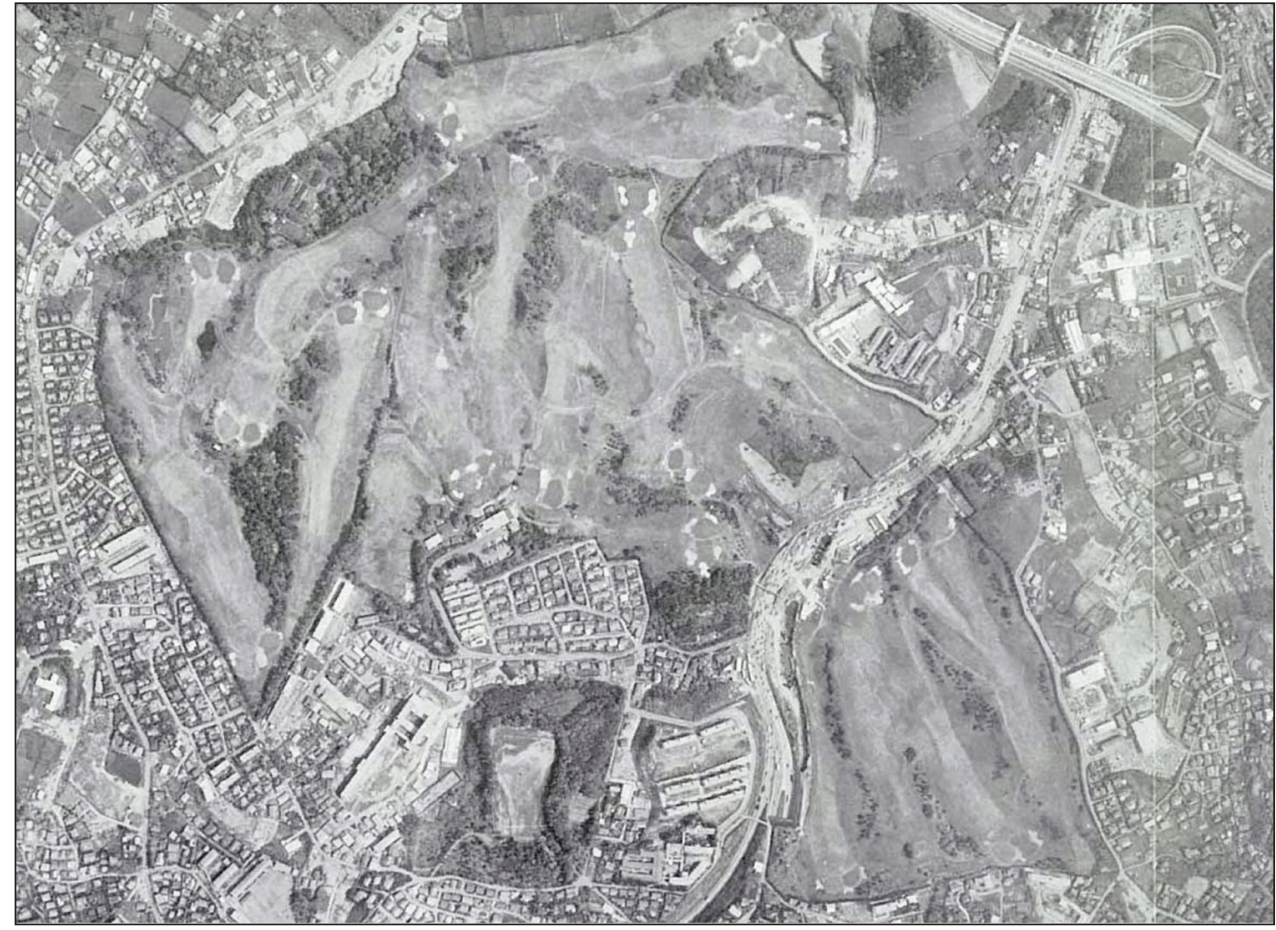

Fig. 7. Bird's-eye view of the Hodogaya Country Club before 1968.

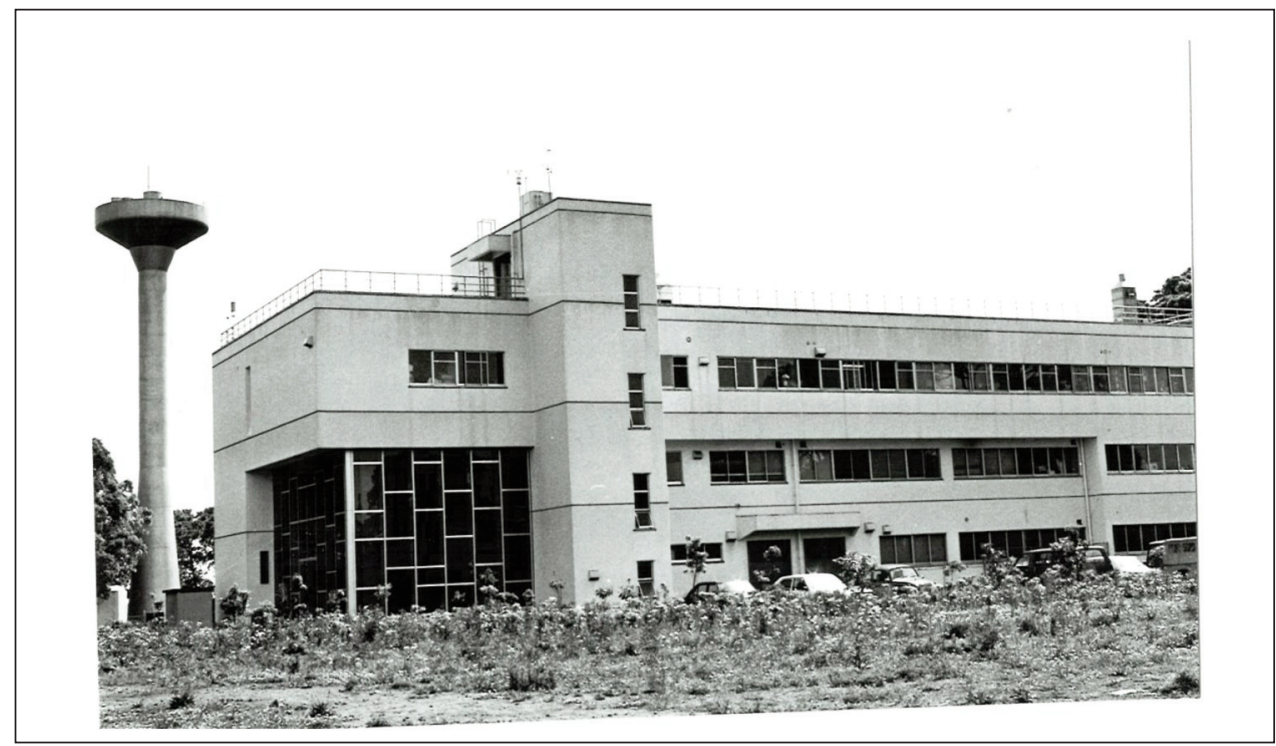

Fig. 8. Planted saplings around the former Institute of Environment and Information Science and Technology (March 1977). 
The construction of Yokohama National University was begun in 1968. The first reforestation was begun surrounding the former Institute of Environmental Information and Science* on March in 1976. The method of restoration of natural forest is the so-called Miyawaki method. It involves: 1) Using saplings (30-80 cm high) of natural forest species, especially canopy species, with root systems already well developed from growth in pots; 2) Planting different species in spatially random mixtures; and 3) Planting densely, with 13 individuals per square meter. Plantation at Yokohama National University used 1-1.5 individuals per square meter. In March 1979, the 30th Anniversary and Integrated Memorial Environmental Conservation Forest Creation Plan was carried out, based on the 30th Anniversary and Integrated Memorial Environmental Conservation Forest Creation Plan. It had four aspects: 1) The area around the school site would be surrounded by a border environmental conservation forest with a width of $10 \mathrm{~m}$ inside and outside. 2) For planting, we would use local species, especially evergreen broad-leaved trees, which will grow to a height of $20 \mathrm{~m}$ or more in the future depending on the location conditions. 3 ) The best use would be made of existing trees on the premises; single-tree value planting should be a three-dimensional green zone that forms a multi-layered structure. When single trees are planted, they should be as few as possible. 4) Around the school building of each faculty, independence of each faculty should be respected, based on the above basic principles (Miyawaki 1979). The university staff contributed for this plantation, with each Professor paying 3000 yen, each Associate Professor 2000 yen, and each Assistant 1000 yen. This plantation area was between the main gate to the executive office of YNU and the central square.

The other forests of Meiji Jingu and Institute for Nature Study were built to plant mature trees for landscaping.

\section{Methodology of comparison and analysis}

The Forest of Meiji Jingu shrine had three comprehensive field surveys; results from two recent surveys (Miyawaki \& al. 1980; Okuromi \& al. 2013) were compared and analyzed for the purpose. The forests, especially huge old Castanopsis cuspidata var. sieboldii forests, are kept on the old embankment at the Institute for Nature Study. The natural forests being restored were planted densely and randomly with saplings of canopy specie of natural evergreen broad-leaved forest.

The purposes of this paper are to compare each forest and analyze successors, comparing changes of height and cover, and growth behaviour of saplings.

1) Comparison of flora of different years at each site;

2) Comparison of successors was done by means of frequency tables for each stratum, based on phytosociological tables;

3) Tables for newcomers and disappearing species;

4) Comparison of height and cover range on graphs; and

5) For the sapling plantation, three different plantation sites were compared with data from two tree surveys.

*Institute was integrated in Graduate School of Environment and Information Sciences on April, 2001. 


\section{Results}

\section{A. Meiji Jingu Shrine}

\section{Forest development of Meiji Jingu Shrine}

The forest of Meiji Jingu was a planted site with 122,572 donated and transplanted trees (Table 1), and remaining trees before construction. These trees were planted based on a design by Hongo 1923 (Fig. 6). The tree survey in 2012 at the shrine forest of Meiji Jingu (Hamano \& al. 2013) confirmed 1,764 conifer trees and found that 3,668 trees (68\%) had disappeared from the first survey in 1980 (Ishigami 1980). Especially Pinus thunbergii and Taxus cuspidata decreased by more than 90\%; Pinus densiflora decreased $80 \%$; and Chamecyparis obtusa, C. picifera, Cryptomeria japonica, Abies firma and Tsuga sieboldii decreased around 50-60\%. On the other hand, 26,192 evergreen broad-leaved trees were confirmed and 98,404 trees had disappeared (79\%). Especially, Ilex integra and Ternstroemia gymnanthera decreased 30-40\%; and Castanopsis cuspidata var. sieboldii, Quercus myrsinaefolia, Q. acuta, Q. glauca, Cinnamomum camphora and Cleyera japonica decreased $50-55 \%$.

These results showed the first planting scheme developed close to the expected final forest face (Hongo 1923) in 2012; ca 100 years after plantation (Fig. 9).

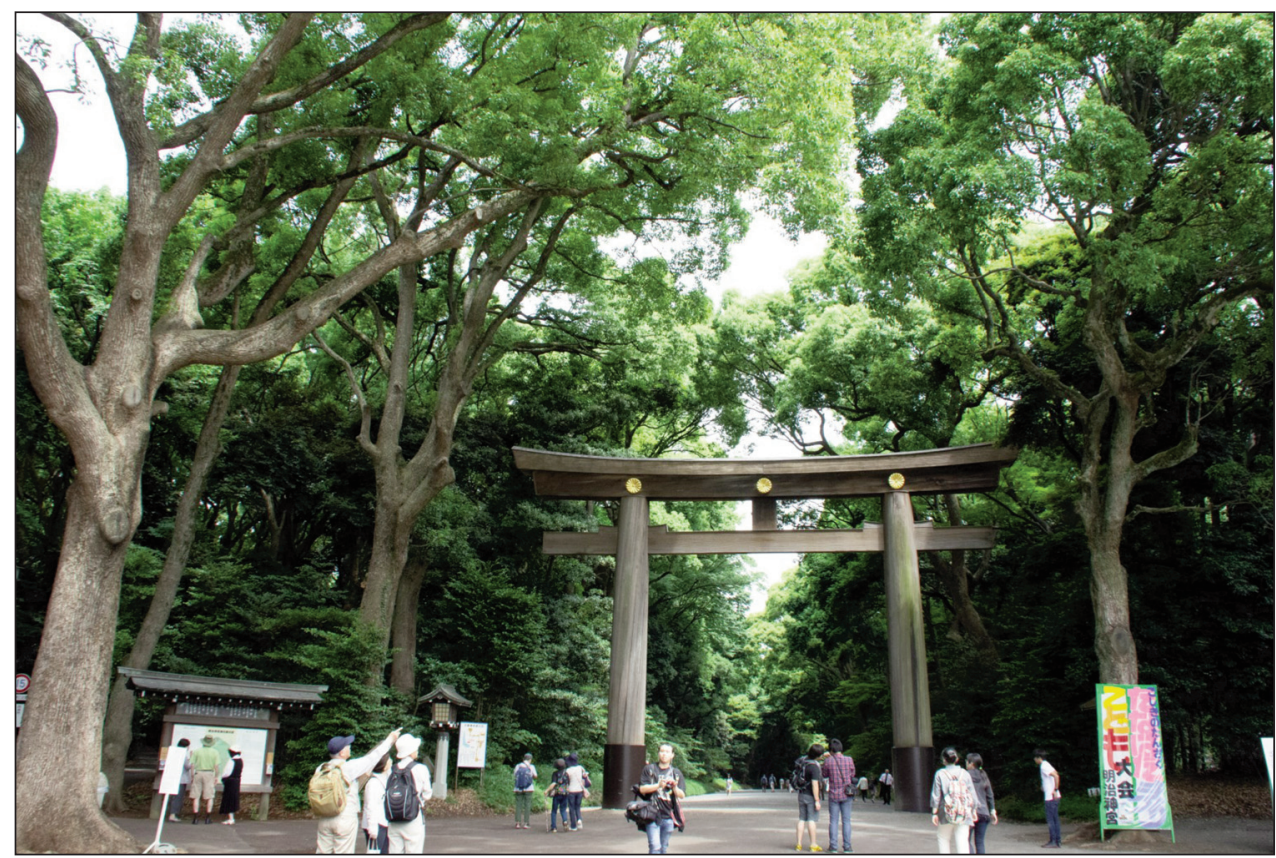

Fig. 9. The main entrance of Meiji Jingu. Technology (March 1977). 
2. Comparison of forest composition

\section{1) Flora}

The flora of shrine forest of Meiji Jingu was surveyed in 2012, confirming seed plants from 110 families and 586 species, with 234 woody plants, 352 herbs and 63 exotic species. Hamano 2012 compared the flora in 1980 (Honda \& al. 1980): woody plants had decreased by 60 species from 294 species (1980) to 234 species (2012) (Hamano 2013), and ca 130,000 trees (Hamano \& al. 2013). Families decreased from 150 families in 1980 to 110 families (2012). Herb species decreased a little, from 358 species (1980) to 352 species (2012). Exotic species increased from 34 species (1980) to 63 species (2012).

For species of evergreen broad-leaved forest rather than the total flora, several species increased, including Quercus sessilifolia, Sarcandra glabra, Prunus spinulosa, Elaeagnus glabra, Ophiopogon jaburan, Cinnamomum sieboldii, Rhaphiolepis indica var. umbellata*, Symplocos prunifolia, Arisaema ringens, and Farfugium japonicum. [*shows bird dispersal from garden.] Disappearing species were Lithocarpus glaber, Quercus $\times$ yokohamensis, Celtis sinensis var. japonica f. longifolia, Michelia compressa, Daphniphyllum teijsmannii, Ilex pedunculosa and Pieris japonica*. These species are not native in Tokyo. Endangered species of secondary forest in Tokyo appeared well in 2012, including Erythronium japonicum, Polygonatum odoratum var. pluriflorum, Carex oshimensis, Calanthe discolor, Cephalanthera erecta, Cephalanthera falcata, Cephalanthera longibracteata, Cymbidium macrorhizon, Epipogium roseum Liparis nervosa. Even some secondary-forest species disappeared, including Lindera glauca, Lindera umbellata, Kalopanax septemlobus, Pertya scandens, and Carex conica (Table 2).

\section{2) Community composition}

Okutomi \& al. (2012) found newcomers in the evergreen broad-leaved forest, based on comparison of the Cinnamomum camphora-Castanopsis cuspidata var. sieboldii community surveyed in Miyawaki (1980) and Okutomi \& al. (2012).

Newcomers were Ophiopogon ohwii, O. yaburan, Sarcandera glabra, Euonymus japonucum, Pittosporum tobira, Distilium racemosum, Cinnamomum sieboldii and Tsuga sieboldii. Newcomers are mostly bird-dispersed species, which may come from gardens surrounding the Meiji Jingu. O. yaburan, Sarcandra glabra, Euonymus japonicum, Pittosporum tobira, Distilium racemosum, and Cinnamomum sieboldii are considered escaped from gardens. On the other hand, Symplocos lucida (T2, S1, 2, H) was found in $32 \%$ of Cinnamomum camphora-Castanopsis cuspidata var. sieboldii community. Symplocos lucida would have been confused with Ilex integra in 1980, because Ilex integra disappeared in each stratum in 2012 (Table 3). Some species were described as newcomers, including Torreya nucifera in T2, H; Aronia (Photinia) glabra in T2; Illicium anisatum in S1; Quercus phylliraeoides in T2; and Q. salicina in S2. These were in only one stand and in the T2 layer. Therefore, these would have been overlooked in 1980 . Other deciduous species were pioneers such as Zanthoxylum ailanthoide, Elaeagnus umbellata, Melia azedarach, Botrychium japonicum, Oplismenus undulatifolius, Trichosanthes kirilowii var. japonica, Erechtites hieracifolia, and Akebia trifoliata. 
Fujiwara: Can restored forests retrieve the flora of potential natural forests...

Table 2. Newcomer and disappearing natural-forest species in ca 40 years at Meiji Jingu, in the second flora survey by Hamano (2013).

\begin{tabular}{|c|c|}
\hline Newcomer species & Disappearing species \\
\hline \multicolumn{2}{|c|}{ Species of evergreen broad-leaved forest } \\
\hline Quercus sessilifolia & Lithocarpus glaber \\
\hline Sarcandra glabra & Quercus $\times$ yokohamensis \\
\hline Prunus spinulosa & Celtis sinensis var. japonica f. longifolia \\
\hline Elaeagnus glabra & Michelia compressa \\
\hline Ophiopogon jaburan & Daphniphyllum teijsmannii \\
\hline Cinnamomum sieboldii & Ilex pedunculosa \\
\hline Rhaphiolepis indica var. umbellata & Pieris japonica \\
\hline Symplocos prunifolia & etc. \\
\hline \multicolumn{2}{|l|}{ Arisaema ringens } \\
\hline \multicolumn{2}{|l|}{ Farfugium japonicum } \\
\hline \multicolumn{2}{|l|}{ etc. } \\
\hline \multicolumn{2}{|c|}{ Species of secondary forest and endangered species in Tokyo } \\
\hline Erythronium japonicum & Lindera glauca \\
\hline Polygonatum odoratum var. pluriflorum & Lindera umbellata \\
\hline Carex oshimensis & Kalopanax septemlobus \\
\hline Calanthe discolor & Pertya scandens. \\
\hline Cephalanthera erecta & Carex conica \\
\hline Cephalanthera falcata & etc. \\
\hline \multicolumn{2}{|l|}{ Cephalanthera longibracteata } \\
\hline \multicolumn{2}{|l|}{ Cymbidium macrorhizon } \\
\hline \multicolumn{2}{|l|}{ Epipogium roseum } \\
\hline \multicolumn{2}{|l|}{ Liparis nervosa } \\
\hline etc. & \\
\hline
\end{tabular}

These species occur in gaps. In total, 47 new species appeared in 2012 (Okutomi \& al. 2013). Species disappearing from 1980 to 2012 were 78 (Okutomi \& al. 2013).

These were mostly pioneer species, but some evergreen broad-leaved species disappeared also, including Michelia compressa, Ilex latifolia, Osmanthus ilicifolium, Rhodea japonica, Elaeocarpus sylvestris, and Ophiopogon planiscapus. These species occurred in one or two stands.

Comparison of height and cover in each forest stratum at Meiji Jingu, in 1980 and 2012, is shown in Fig. 10. The canopy layer (T2) in 1980 changes to super-tree layer (ST) in 2012 with tree growth, but width of tree layer coverage is different within $10 \%$. Shrub layer in 1980 grew up to tall shrub and short shrub layers in 2012. Width of coverage became half of the 1980 coverage. The seedlings of herb layer $(\mathrm{H})$ in 1980 grew up to short shrub layer (S2) in 2012 and width of coverage is both similar. Mean coverage of 2012 is lower than 1980 because the herb layer $(\mathrm{H})$ of 1980 includes seedlings and herbs. 


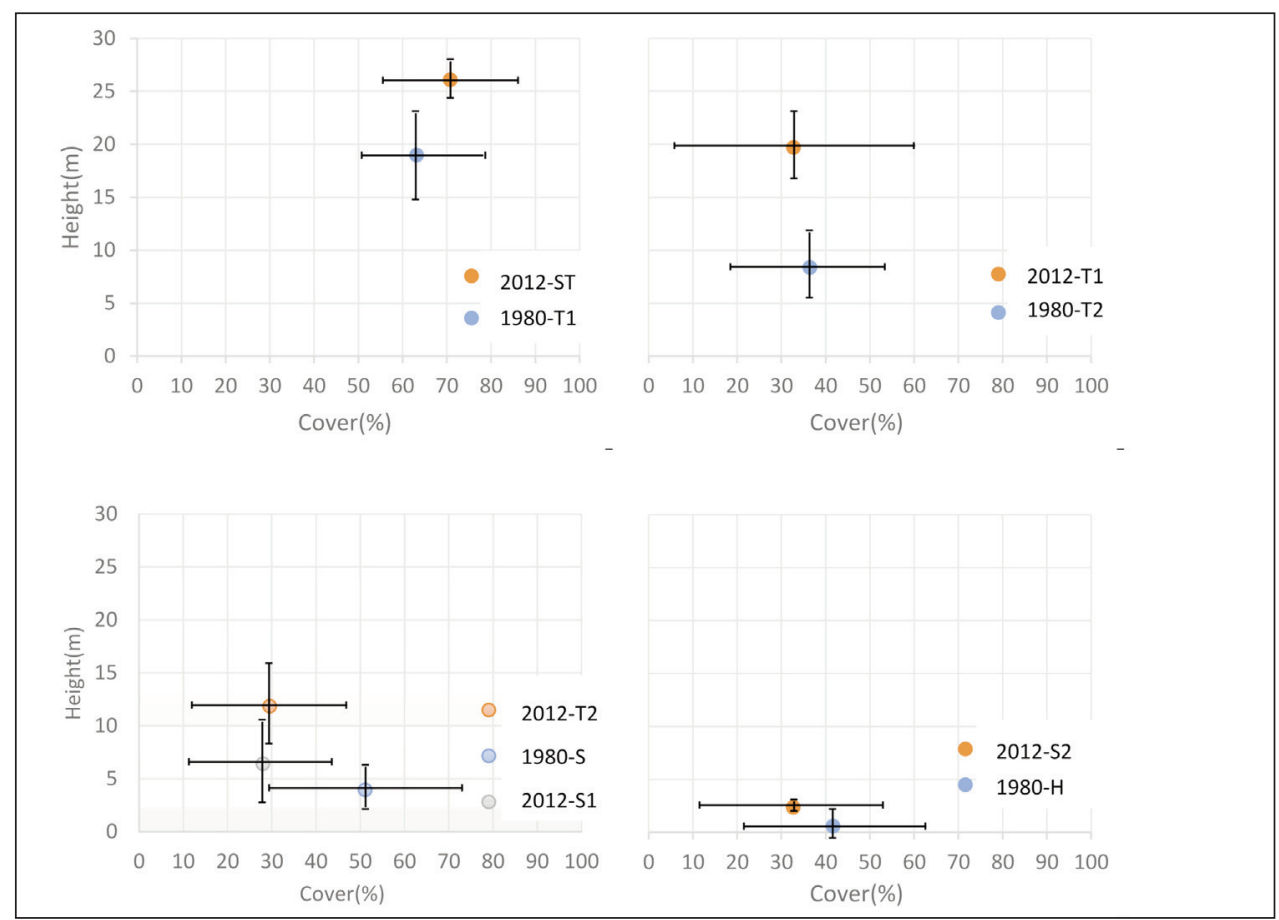

Fig. 10. Comparison of height and cover in each forest stratum at Meiji Jingu, in 1980 and 2013.

ST: super tree layer; T1: Canopy layer; T2: Sub-canopy layer; S: shrub layer; S1: tall shrub layer; S2: short shrub layer; H: herb layer.

\section{3) Main species trends in each layer}

In order to see the trends of forest successors, the vegetation coverage of each layer for each species was compared by frequency numbers.

Trends of evergreen trees from 1980 to 2012 are very important to develop forest for the future. Cinnamomum camphora and Castanopsis cuspidata var. sieboldii are canopy trees, but Cinnamomum camphora is not native in Tokyo. The Cinnamomum frequency in the canopy layer is high (IV) and did not change in 30 years; its coverage increased since 1980. The frequency of Cinnamomum decreased in the shrub and herb layers. Successor seedlings also decreased (Table 3).

Castanopsis cuspidata var. sieboldii with Quercus myrsinaefolia composes one of the natural forest types in the Meiji Jingu area (Okutomi \& al. 1987). Meiji Jingu is located on the borderline between the natural areas of Ardisio-Castanopsietum sieboldii and Quercetum myrsinaefoliae (Okutomi \& al. 1987; Okutomi \& al. 2013).

The frequency of Castanopsis in the T2 layer was high in 1980, but some trees of Castanopsis grew up to the ST layer, and the rest remained in the T1 layer. Half of the herb-layer individuals of Castanopsis grew up to the S2 layer in 2012, and the other half remained in the herb layer. Castanopsis occurs evenly in each layer. Usually Castanopsis cannot produce new seedlings so well because the acorns are eaten easily by insects. Seedlings in the forest are relatively few. 


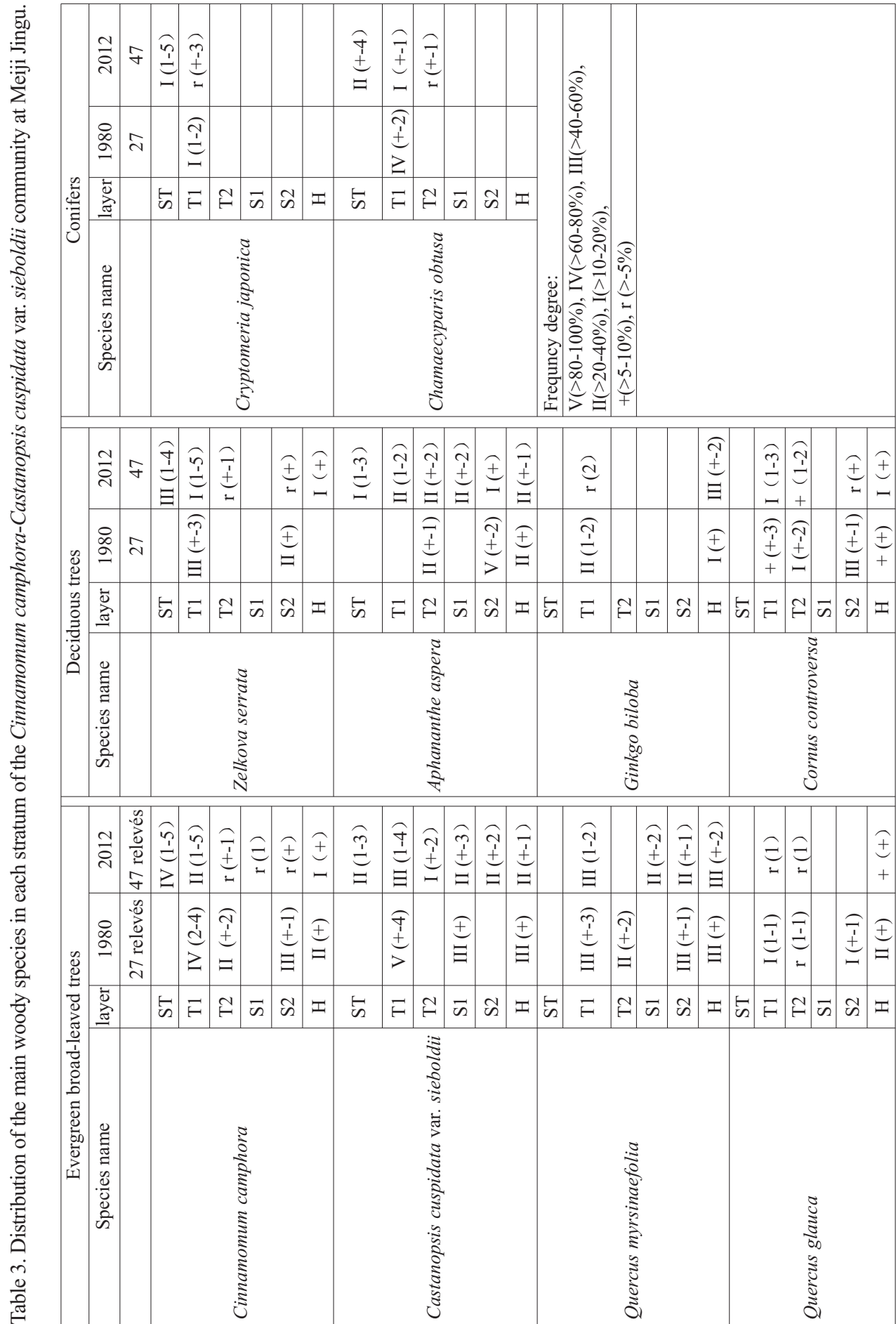




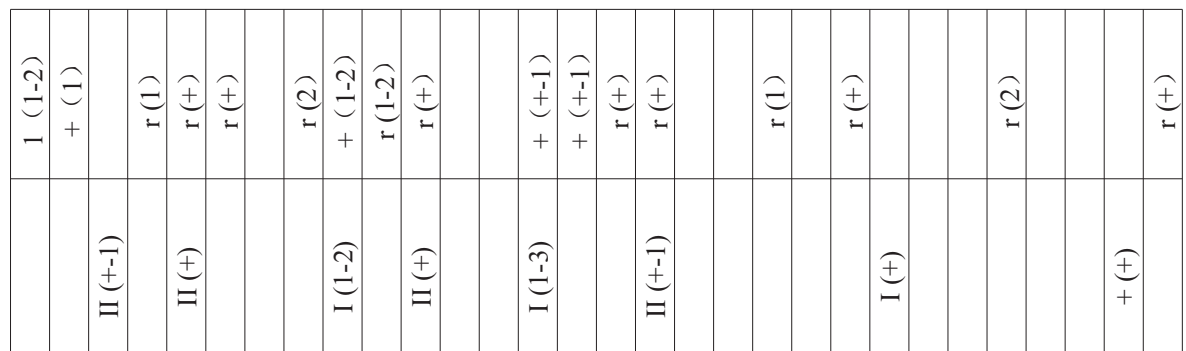

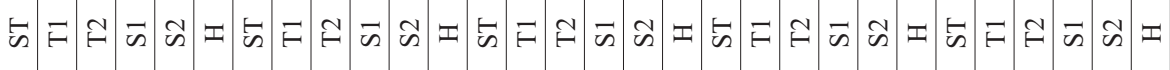

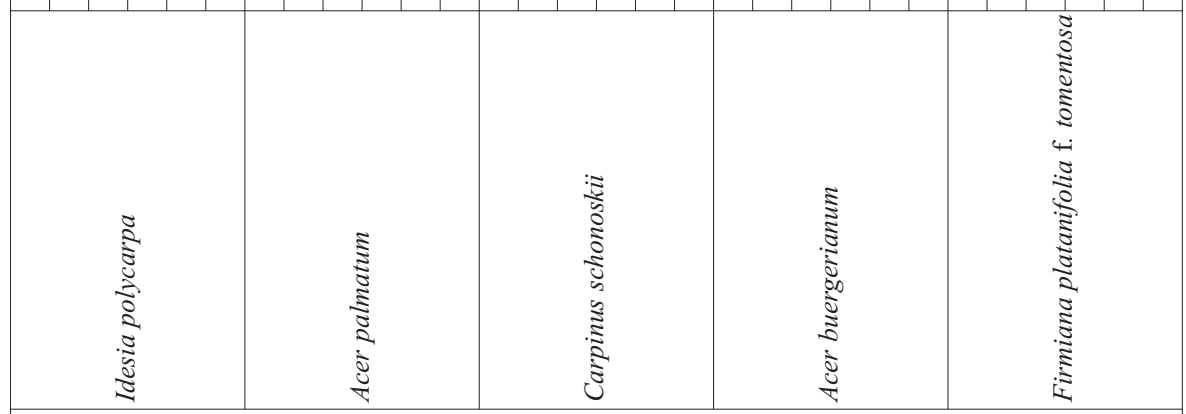

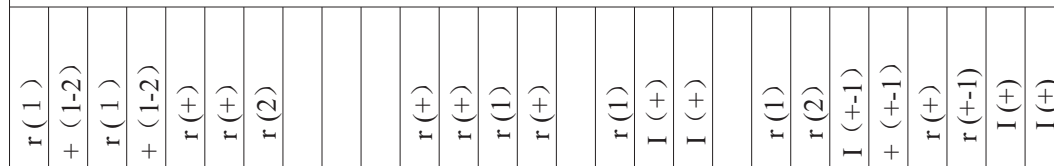

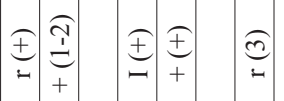

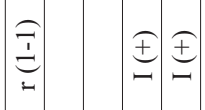

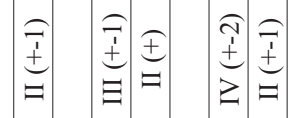

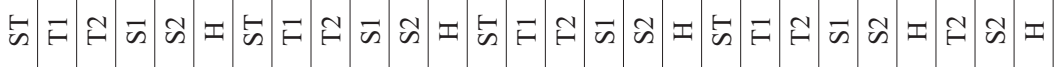

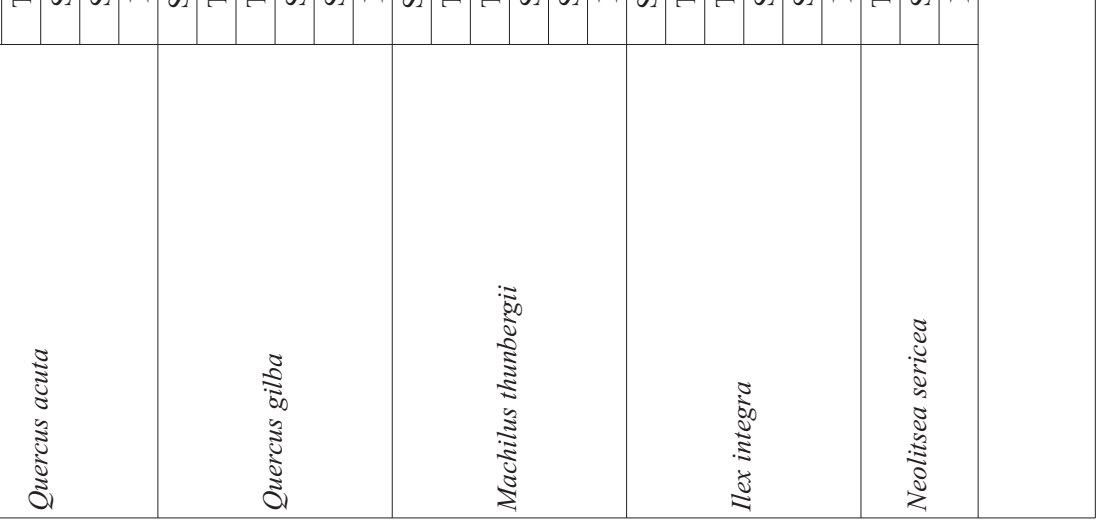


Quercus myrsinaefolia also occurs in each layer. Even the herb layer has the same frequency in 1980 and 2012. Castanopsis and Q. myrsinaefolia will have successors into the future.

On the other hand, Q. glauca and Quercus acuta have lower frequency than r-1.

Quercus gilva and Machilus thunbergii are similar. These species have few individuals and very fewer successors. Ilex integra and Neolitsea sericea were more than $25 \%$ in the shrub layer, but these decreased in the 2012 survey (Table 3).

The frequency of deciduous trees in canopy layer, such as Zelkova, is as high as in 1980. But Zelkova does not have successors. Aphananthe aspera and Cornus controversa had high frequency (III) in the shrub layer, but the frequency of these species decreased in each layer in 2021. The other deciduous tree species, such as Idesia polycarpa, Acer palmatum, and Carpinus tschonoskii, do not have successors. As the canopy layer of the Cinnamomum camphoraCastanopsis cuspidata var. sieboldii community closes, deciduous trees disappear. Acer buergerianum and Firmina platanifolia f. tomentosa are already less frequent $(\mathrm{r}-+)$ in some layers.

\section{B. The Institute for Nature Study of the National Museum of Nature and Science}

The Institute for Nature Study supplied trees for transplanting at the Meiji Jingu in 1915. Especially, huge trees of Castanopsis cuspidata var. sieboldii on the old embankment and Pinus thunbergii were transplanted. The Castanopsis trees remaining after transplanting to Meiji Jingu were 234, as measured and calculated in 1972 (Okuda 1972). The age of Castanopsis is estimated to be 400 years old (Fig. 11). Of these, 22 individuals were restored to the forest after being relocated during the standing towing work for highway construction.

\section{1) Newcomers and disappearing species}

Okuda described newcomers and disappearing species five years after forest restoration. Comparison of vegetation composition showed five new species of evergreen plants and 10 new deciduous species (Table 4). The newcomer species were seedlings of Aucuba japonica, Neolitsea sericea, Ligustrum japonicum, and shrubs of Camellia japonica, Eryobotrya japonica and Hedera rhombea. Deciduous new species were secondary species such as Styrax japonica, Euonymus sieboldiana, Prunus grayana, Callicarpa japonica, etc. Twenty pioneer or secondary species disappeared (Okuda 1972). When the canopy closes and the surrounding area has forests, forest species can come back in as little as five years.

Okuda (1980) compared vegetation change over 15 years since 1966 and compared forest change since then in 2013. The results were: 1. Old, gnarled Castanopsis trees had become remarkable (Okuda 1972), and tree vigor weakened (Okuda 1980, 2013); 2. Forests dominated by Quercus acuta are alive, but the Castanopsis canopy had weakened slightly; young trees of Castanopsis were growing well (Okuda 2013). The coverage of individual species changed. In the understorey there is remarkable growth of Trachycarpus fortunei, Ligustrum japonicum and the vine Stauntonia hexaphylla. Coverage of shrub-layer species such as Ligustrum japonicum, Machilus thunbergii, Ternstroemia gymnanthera, Trachelospermum asiaticum, and Kadzura japonica increased. Newcomers in the herb layer were Ficus erecta, Cinnamomum japonicum, Zanthoxylum ailanthoides, Pollia japonica, etc. (Okuda 2013). 


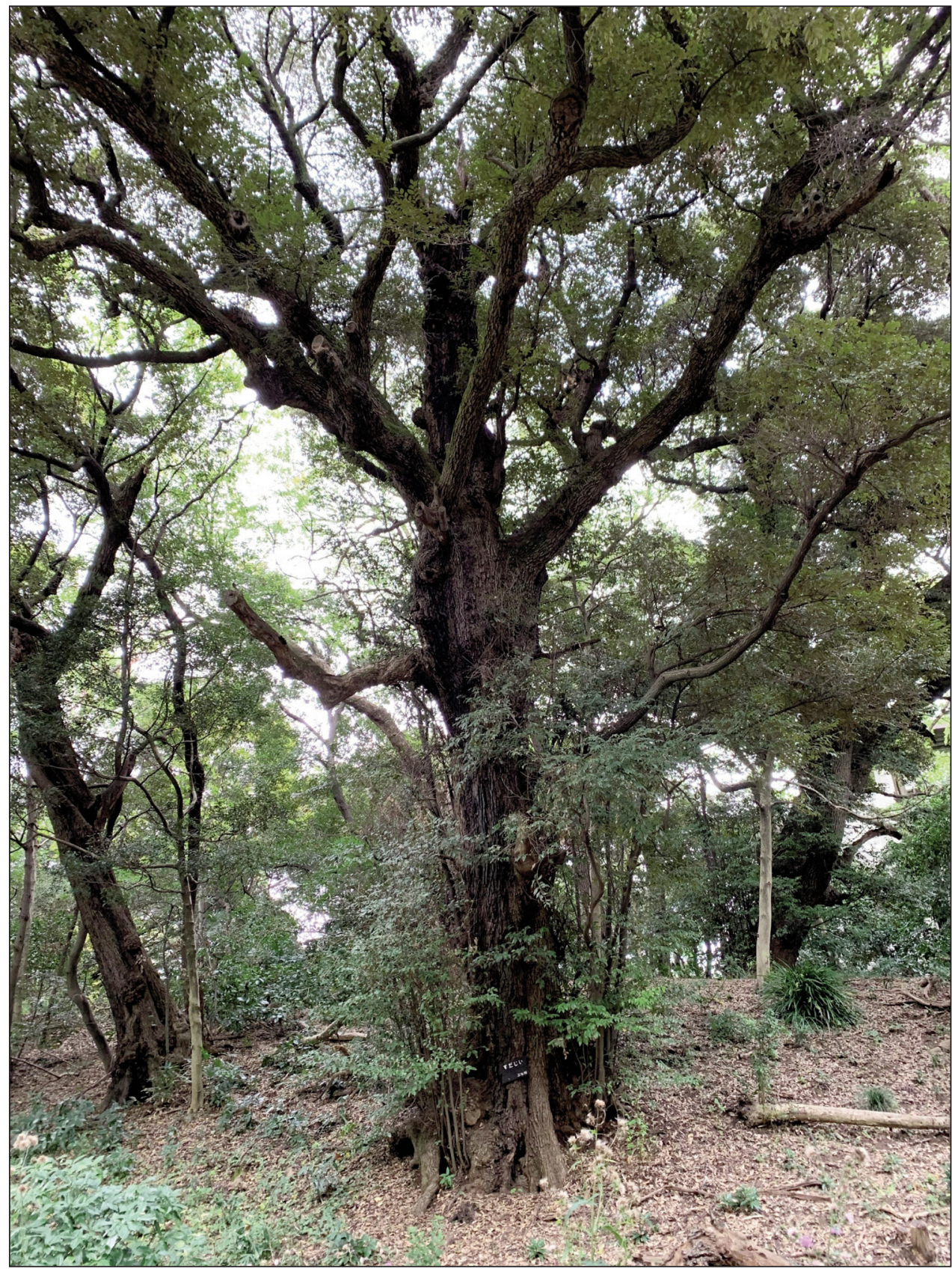

Fig. 11. Castanopsis cuspidata var. sieboldii forest on the long old embankment at the Instutute for Nature Study. 
Table 4. Newcomers and disappearing species after five years of the standing towing work for highway construction at the Institute for Nature Study.

\begin{tabular}{|c|c|c|c|}
\hline \multicolumn{4}{|c|}{ Newcomers } \\
\hline \multicolumn{2}{|c|}{ Shrub layer } & \multicolumn{2}{|r|}{ Herb layer } \\
\hline Evergreen species & Deciduous species & Evergreen species & Deciduous species \\
\hline Camellia japonica & Styrax japonica & Aucuba japonica & Prunus grayana \\
\hline Eryobotrya japonica & Euonymus sieboldiana & Neolitsea sericea & Callicarpa japonica \\
\hline \multirow[t]{6}{*}{ Hedera rhombea } & & Ligustrum japonicum & Smilax china \\
\hline & & Pleioblastus chino & Akebia quinata \\
\hline & & & Oplismenus undulatifolius \\
\hline & & & Arisaema urashima \\
\hline & & & Parthenocissus tricuspidata \\
\hline & & & Rubus hirsuta \\
\hline \multicolumn{4}{|c|}{ Disappearing species } \\
\hline Evergreen species & Deciduous species & Evergreen species & Deciduous species \\
\hline Quercus myrsinaefolia & Clerodendron japonicus & & Macleaya cordata \\
\hline \multirow[t]{16}{*}{ Pleioblastus chino } & Rhus javanica & & Dioscorea tokoro \\
\hline & Mallotus japonicus & & D. japonica \\
\hline & & & Trichosanthes cucumeroides \\
\hline & & & Viola grypoceras \\
\hline & & & $\begin{array}{l}\text { Eupatorium chinensis var. simplicifo- } \\
\text { lium }\end{array}$ \\
\hline & & & Conyza canadensis \\
\hline & & & Thelypteris viridifrons \\
\hline & & & Fatoua villosa \\
\hline & & & Zanthoxylum schinifolium \\
\hline & & & Solanum lyratum \\
\hline & & & Thelypteris decursiva-pinnata \\
\hline & & & Vibrunum dilatatum \\
\hline & & & Celastrus obtusifolius \\
\hline & & & Festuca paruigluma \\
\hline & & & Boehmeria japonica var. longispica \\
\hline & & & Solanum nigrum \\
\hline
\end{tabular}

\section{2) Successors in each layer in Castanopsis forests}

The Castanopsis cuspidata var. sieboldii forest at the Institute for Nature Study is classified in the Quercus acuta-Castanopsis cuspidata var. sieboldii community (Okuda 1969) and the Ardisio-Castanopsietum sieboldii (Okuda 1969, 1970). 
Castanopsis forests at the Institute for Nature Study were classified into the Camellia japonica subunit (F1, F2) and the typical unit (F3) (Okuda 1966). The Camellia subunit was differentiated by Camellia japonica and Ilex integra, and occurred on the embankment that was believed to have been built in the Muromachi period (1336-1573) (Institute for Nature Study of National Museum of Nature and Science 1999). Some of the older, larger pines in the Institute for Nature Study's modern gardens are thought to have been among the very trees that grew in Matsudaira's garden in the Edo Period (1664). The Camellia subunit has a Ternstroemia gymnanthera sub-subunit of the subunit (F1) and a typical subsubunit of the subunit (F2). The Ternstroemia gymnanthera sub-subunit has a mean species number of 44, the typical sub-subunit (F2) has 40, and the typical subunit (F3) has 38 . Castanopsis and Quercus acuta occur in Pinus thunbergii forests too (F4). The Pinus forest has a mean species number of 47, which was the highest number (Table 5). Cover in each stratum of Castanopsis cuspidata var. sieboldii forest and Pinus thunbergii forest in 1966 is shown in Fig. 12.

The successors of Castanopsis forests were analyzed based on Okuda \& Miyawaki 1966 (Table 5) and 2013 (Okusa 2013). Table 5 shows the frequency and cover of the main woody species for checking successors.

The important view is whether successors of canopy trees can keep a high frequency and coverage in the shrub and herb layers. Castanopsis cuspidata var. sieboldii in the Ardisio-Castanopsietum on the embankment has frequent seedlings in the herb layer in F1 and F4 (Table 5). The cover of the Castanopsis successors is less than 5\% in F1 and F3, despite high frequency (IV, V) in the herb layer. Castanopsis occurs in the shrub layer with high frequency (IV, V) and relatively high coverage (+-4). Frequency (I) in the subcanopy tree layer (T2) is low. Even so, Okuda (2013) described that young Castanopsis grew up. Quercus acuta occurs with lower frequency in the canopy layer, shrub layer and herb layer. The Camellia subunit has high frequency of Camellia and Ilex in the shrub layer (IV, III), and Ternstroemia has high frequency in the herb layer (V). The Pinus forests were differentiated by Pinus thunbergii and P. densiflora (F4). Pinus occurs only in the canopy and subcanopy, with no successors in the shrub and herb layers. The canopy layer is relatively open (coverage 2-3). The frequency of Castanopsis in the shrub and herb layers of Pinus forests is high (IV-V) because the high penetration of sunlight helps the broad-leaved trees grow well. Even Quercus acuta has high frequency in the herb layer (III). Another evergreen broad-leaved species, Machilus thunbergii, has high frequency in the herb layer of the Camellia subunit (IV, 2) and subcanopy layer (IV) in the typical subunit of Castanopsis forest. Machilus has high frequency in the shrub layer of Pinus forest (III). Quercus myrsinaefolia occurs with high frequency (IV) in the herb and shrub layers of Pinus forests. Other evergreen broad-leaved woody species have low frequency.

The deciduous woody species, Aphananthe aspera, has high frequency (V) in the shrub layer of all forests. Quercus serrata occurs with high frequency in the herb layer (II, V) of all forests, but there is no guarantee that these seedlings will grow in the shade.

The successors in the Castanopsis forests in Institute for Nature Study were relatively good. And the situation is improved in Okuda (2013) without data. 
Table 5. Comparison of woody species in various strata of Castanopsis cuspidata var. sieboldii forest and Pinus thunbergii forest at the Institute for Nature Study.

\begin{tabular}{|c|r|r|r|r|}
\hline Running number & F1 & F2 & F3 & F4 \\
\hline Number of relevés & 8 & 4 & 5 & 5 \\
\hline Mean number of species & 44 & 40 & 38 & 47 \\
\hline
\end{tabular}

Differential species of Castanopsis forest and Pinus forest at the Institute for Nature Study

Castanopsis cuspidata var. sieboldii

\begin{tabular}{|c|c|c|c|c|}
\hline $\mathrm{T} 1$ & $\mathrm{~V}(3-5)$ & $4(4)$ & $\mathrm{V}(3-5)$ & \\
\hline $\mathrm{T} 2$ & $\mathrm{I}(3)$ & $1(1)$ & $\mathrm{I}(1)$ & \\
\hline $\mathrm{S}$ & $\mathrm{IV}(1-3)$ & $4(+-4)$ & $\mathrm{IV}(+-4)$ & $\mathrm{V}(+-3)$ \\
\hline $\mathrm{H}$ & $\mathrm{V}(+)$ & $2(+-1)$ & $\mathrm{II}(1-2)$ & $\mathrm{IV}(+)$ \\
\hline $\mathrm{T} 1$ & $\mathrm{II}(+-2)$ & $1(+)$ & & $\mathrm{I}(+)$ \\
\hline $\mathrm{T} 2$ & & & & $\mathrm{I}(+)$ \\
\hline $\mathrm{S}$ & $\mathrm{II}(+-1)$ & $2(+)$ & $\mathrm{I}(+)$ & $\mathrm{I}(+)$ \\
\hline $\mathrm{H}$ & $\mathrm{II}(+)$ & $2(+)$ & $\mathrm{I}(+)$ & $\mathrm{III}(+)$ \\
\hline
\end{tabular}

Differential woody species of sub-units:

Ilex integra

\begin{tabular}{|c|c|c|c|c|}
\hline $\mathrm{T} 1$ & $\mathrm{II}(1)$ & $1(1)$ & & \\
\hline $\mathrm{T} 2$ & $\mathrm{I}(2)$ & & & \\
\hline $\mathrm{S}$ & $\mathrm{III}(+-2)$ & $2(+)$ & $\mathrm{II}(+)$ & \\
\hline $\mathrm{H}$ & $\mathrm{I}(+)$ & $1(+)$ & & \\
\hline $\mathrm{T} 2$ & $\mathrm{I}(1)$ & $1(1)$ & $\mathrm{I}(+)$ & \\
\hline $\mathrm{S}$ & $\mathrm{IV}(+-3)$ & $3(+)$ & & \\
\hline $\mathrm{H}$ & $\mathrm{II}(+)$ & & & \\
\hline $\mathrm{S}$ & $\mathrm{IV}(+)$ & & & \\
\hline $\mathrm{H}$ & $\mathrm{V}(+)$ & $1(+)$ & & $\mathrm{I}(+)$ \\
\hline
\end{tabular}

Differential species of Pinus forest:

\begin{tabular}{|l|c|l|l|l|c|}
\hline Pinus thunbergii & T1 & & & V(2-3) \\
\hline \multirow{2}{*}{ Pinus densiflora } & T1 & & & & III $(1-3)$ \\
\cline { 2 - 5 } & T2 & & & & II (1-2)
\end{tabular}

Evergreen woody species:

Machilus thunbergii

Quercus myrsinaefolia

Cleyera japonica

Dendropanax trifidus

Quercus paucidentata

Eriobotrya japonica*

\begin{tabular}{|c|c|c|c|c|}
\hline T1 & & & $\mathrm{I}(2)$ & \\
\hline $\mathrm{S}$ & $\mathrm{I}(1)$ & $1(+)$ & $\mathrm{IV}(+)$ & $\mathrm{III}(+)$ \\
\hline $\mathrm{H}$ & $\mathrm{IV}(+)$ & $2(+)$ & $\mathrm{II}(+-1)$ & $\mathrm{II}(+-1)$ \\
\hline $\mathrm{T} 2$ & & & $\mathrm{I}(+)$ & $\mathrm{I}(1)$ \\
\hline $\mathrm{S}$ & $\mathrm{I}(+)$ & & $\mathrm{I}(1)$ & $\mathrm{IV}(+)$ \\
\hline $\mathrm{H}$ & $\mathrm{I}(+)$ & $2(+)$ & $\mathrm{II}(+)$ & $\mathrm{IV}(+)$ \\
\hline $\mathrm{S}$ & $\mathrm{I}(+)$ & & & $\mathrm{II}(+-1)$ \\
\hline $\mathrm{H}$ & $\mathrm{I}(+)$ & & & $\mathrm{I}(+)$ \\
\hline $\mathrm{S}$ & $\mathrm{II}(+)$ & & & \\
\hline $\mathrm{H}$ & & $1(+)$ & & \\
\hline $\mathrm{H}$ & $\mathrm{I}(+)$ & & & \\
\hline $\mathrm{H}$ & $\mathrm{II}(+)$ & $1(+)$ & $\mathrm{I}(+)$ & \\
\hline
\end{tabular}


Table 5. continued.

Deciduous woody species:

\begin{tabular}{|c|c|c|c|c|c|}
\hline \multirow{4}{*}{ Aphananthe aspera } & T1 & $\mathrm{II}(2)$ & & & \\
\hline & $\mathrm{T} 2$ & $\mathrm{II}(+)$ & & $\mathrm{I}(+)$ & $\mathrm{I}(+)$ \\
\hline & $\mathrm{S}$ & $\mathrm{V}(+-2)$ & $3(+)$ & $\mathrm{V}(+-2)$ & $\mathrm{V}(+)$ \\
\hline & $\mathrm{H}$ & $\mathrm{II}(+-1)$ & $1(+)$ & $\mathrm{I}(+)$ & \\
\hline \multirow{3}{*}{ Magnolia kobus } & $\mathrm{T} 2$ & & $1(1)$ & III $(+-1)$ & $\mathrm{I}(1)$ \\
\hline & $\mathrm{S}$ & $\mathrm{V}(+)$ & $3(+-1)$ & $\mathrm{II}(+-1)$ & $\mathrm{I}(1)$ \\
\hline & $\mathrm{H}$ & $\mathrm{III}(+)$ & $1(+)$ & $\mathrm{II}(+)$ & III $(+)$ \\
\hline \multirow{4}{*}{ Quercus serrata } & T1 & & & II $(1)$ & \\
\hline & $\mathrm{T} 2$ & & & $\mathrm{I}(1)$ & \\
\hline & $\mathrm{S}$ & $\mathrm{I}(+)$ & & $\mathrm{I}(+)$ & III(+-2) \\
\hline & $\mathrm{H}$ & $\mathrm{V}(+)$ & $3(+)$ & $\mathrm{III}(+)$ & $\mathrm{III}(+)$ \\
\hline \multirow{4}{*}{ Cornus controversa } & T1 & & & $\mathrm{I}(1)$ & III(3-4) \\
\hline & $\mathrm{T} 2$ & $\mathrm{I}(+)$ & $2(1-3)$ & $\mathrm{II}(+-1)$ & $\mathrm{I}(2)$ \\
\hline & $\mathrm{S}$ & $\mathrm{II}(+)$ & & III $(+)$ & \\
\hline & $\mathrm{H}$ & $\mathrm{I}(+)$ & & & \\
\hline \multirow{4}{*}{ Prunus grayana } & T1 & & $1(2)$ & $\mathrm{I}(+)$ & $\mathrm{I}(3)$ \\
\hline & $\mathrm{T} 2$ & $\mathrm{I}(+)$ & & II $(1)$ & III $(+-1)$ \\
\hline & $\mathrm{S}$ & $\mathrm{III}(+-1)$ & & $\mathrm{I}(2)$ & $\mathrm{III}(+)$ \\
\hline & $\mathrm{H}$ & $\mathrm{II}(+)$ & & & $\mathrm{I}(+)$ \\
\hline \multirow{3}{*}{ Celtis sinensis var. japonica } & $\mathrm{T} 2$ & & & $\mathrm{I}(+)$ & \\
\hline & $\mathrm{S}$ & $\mathrm{II}(+)$ & & $\mathrm{I}(+)$ & \\
\hline & $\mathrm{H}$ & $\mathrm{I}(+)$ & $1(+)$ & & $\mathrm{II}(+)$ \\
\hline \multirow{2}{*}{ Acer palmatum } & $\mathrm{S}$ & $\mathrm{I}(+)$ & $3(+)$ & $\mathrm{II}(+)$ & $\mathrm{IV}(+-1)$ \\
\hline & $\mathrm{H}$ & $\mathrm{I}(+)$ & & $\mathrm{II}(+)$ & $\mathrm{I}(+)$ \\
\hline \multirow{3}{*}{ Styrax japonicus } & $\mathrm{T} 2$ & & & & $\mathrm{III}(+-1)$ \\
\hline & $\mathrm{S}$ & $\mathrm{II}(+)$ & & & $\mathrm{II}(+)$ \\
\hline & $\mathrm{H}$ & $\mathrm{I}(+)$ & $1(+)$ & $\mathrm{II}(+)$ & \\
\hline \multirow{4}{*}{ Idesia polycarpa } & T1 & $\mathrm{III}(+-2)$ & $2(1-2)$ & & \\
\hline & $\mathrm{T} 2$ & & & & $\mathrm{II}(+-4)$ \\
\hline & $\mathrm{S}$ & $\mathrm{II}(+)$ & & $\mathrm{I}(+)$ & $\mathrm{II}(+)$ \\
\hline & $\mathrm{H}$ & $\mathrm{II}(+)$ & & & \\
\hline \multirow{3}{*}{ Zelkova serrata } & T1 & & $1(2)$ & & \\
\hline & $\mathrm{S}$ & $\mathrm{III}(+-2)$ & $1(+)$ & & $\mathrm{I}(+)$ \\
\hline & $\mathrm{H}$ & $\mathrm{I}(+)$ & & $\mathrm{I}(+)$ & $\mathrm{I}(+)$ \\
\hline \multirow{3}{*}{ Mallotus japonicus } & $\mathrm{T} 2$ & $\mathrm{I}(1)$ & $1(2)$ & & $\mathrm{II}(+-1)$ \\
\hline & $\mathrm{S}$ & $\mathrm{I}(+)$ & & & \\
\hline & $\mathrm{H}$ & & $1(+)$ & & \\
\hline \multirow{2}{*}{ Prunus jamasakura } & T1 & & $1(1)$ & & \\
\hline & $\mathrm{T} 2$ & $\mathrm{I}(+)$ & & & $\mathrm{II}(+)$ \\
\hline \multirow{2}{*}{ Cryptomeria japonica } & T1 & & & $\mathrm{I}(+)$ & \\
\hline & $\mathrm{H}$ & $\mathrm{I}(+)$ & & & \\
\hline Castanea crenata & $\mathrm{H}$ & & & & $\mathrm{I}(+)$ \\
\hline \multirow{2}{*}{ Carpinus tschonoskii } & T1 & $\mathrm{I}(1)$ & & & \\
\hline & $\mathrm{S}$ & & & $\mathrm{I}(+)$ & \\
\hline Padus buergeriana & $\mathrm{S}$ & $\mathrm{II}(+)$ & & $\mathrm{I}(+)$ & \\
\hline Phellodendron amurense & $\mathrm{H}$ & $\mathrm{I}(+)$ & & & \\
\hline \multirow{2}{*}{ Styrax obassia } & T1 & II $(1)$ & & & \\
\hline & $\mathrm{T} 2$ & $\mathrm{I}(1)$ & & & \\
\hline Diospyros kaki & $\mathrm{H}$ & $\mathrm{II}(+)$ & & $\mathrm{I}(+)$ & \\
\hline \multirow{2}{*}{ Sapindus mukorossi } & $\mathrm{T} 2$ & & & $\mathrm{I}(+)$ & \\
\hline & $\mathrm{S}$ & & $1(+)$ & & \\
\hline Robinia pseudoacacia & $\mathrm{H}$ & $\mathrm{II}(+)$ & & & \\
\hline Maackia amurensis var. buergeri & $\mathrm{H}$ & $\mathrm{I}(+)$ & & & \\
\hline \multirow{2}{*}{ Ilex serrata } & $\mathrm{S}$ & $\mathrm{I}(+)$ & & & \\
\hline & $\mathrm{H}$ & $\mathrm{I}(+)$ & & & \\
\hline * escaped species & & & & & \\
\hline
\end{tabular}




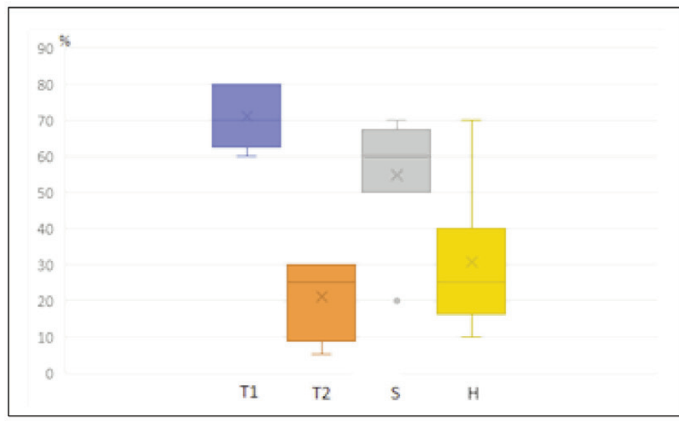

\begin{tabular}{|c|c|}
\hline $\begin{array}{l}\text { a. Ilex integra } \\
\text { Ternstroemia } \\
\text { sub-subunit }\end{array}$ & $\begin{array}{r}\text { subunit, } \\
\text { japonica }\end{array}$ \\
\hline
\end{tabular}

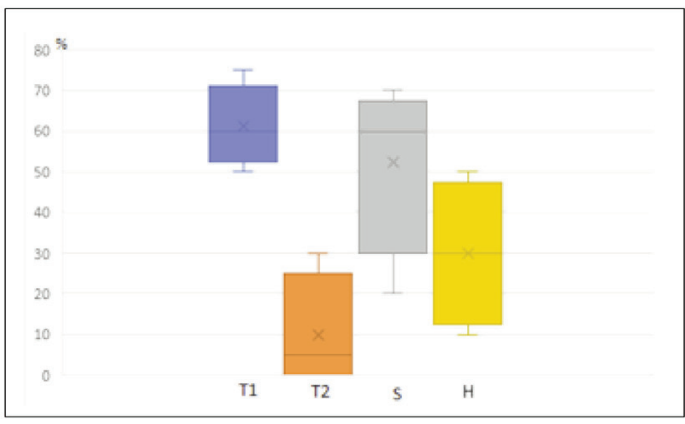

b. Ilex integra subunit,

typical* sub-subunit

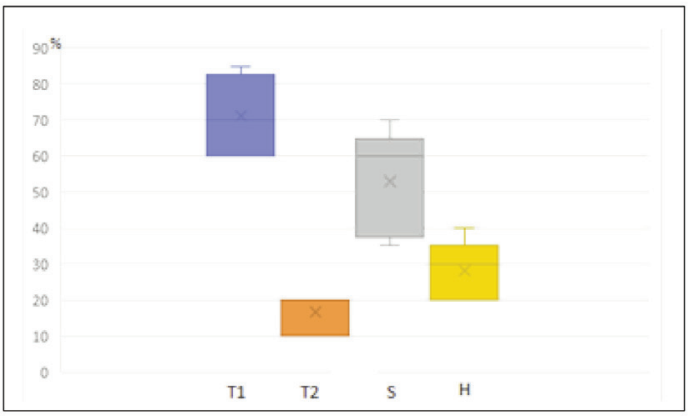

c. Typical* subunit of Castanopsis cuspidata var. sieboldii forest.

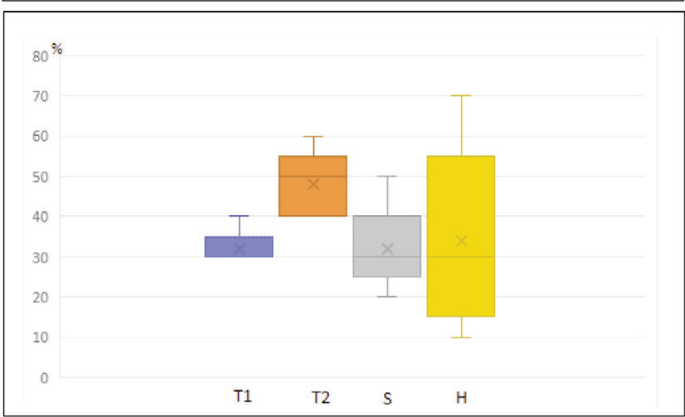

d. Pinus thunbergii forest

Fig. 12. Cover (Y axis) in each stratum (x axis) of Castanopsis cuspidata var. sieboldii forest and Pinus thunbergii forest in 1966 at the Institute for Nature Survey (based on Okuda \& Miyawaki 1966). *Typical means no differential species. 


\section{Yokohama National University}

\section{1) Creation of environmental protection forests and their development}

Yokohama National University was constructed in 1968 on land that was formerly a golf course, with some forest fragments remaining (Fig. 11). After the Institute of Environmental Science and Technology was built (1973), a new idea and ecological technology were used surrounding the new building (March 1976). This idea was to create environmental protection forest from dense, spatially random, mixed-species plantation of native tree species grown as potted saplings in order to guarantee already well-developed root systems (Fig. 8) (Miyawaki \& al. 1974). Planted seedlings grow faster by dense planting (Fig. 13) (Miyawaki \& Fujiwara 1988; Miyawaki \& al. 1993; Fujiwara \& al. 1993).

The potential natural forest of the area of Yokohama National University is Ardisio-Castanopsietum sieboldii (Miyawaki \& al. 1972; Miyawaki 1979). In spite of the potential forest, the production of seedling species was not enough. The planted species were Quercus glauca, Cinnamomum camphora, Machilus thunbergii, Quercus myrsinaefolia and some Castanopsis cuspidata var. sieboldii. These seedlings with 0.4-0.8m height were planted in 1976, at 1-1.5 individuals per square meter, around the building of the former Institute (current $4^{\text {th }}$ building of Graduate School of Environmental and Information Sciences) (Fig. 8); the result in 2018 is shown in Fig. 13.

To commemorate the integration of all faculties on the Tokiwadai campus and the 30th anniversary of the founding of Yokohama National University, the area of environmental protection forests was enlarged by donations of the university staff (professor: 3,000 yen; associate Professor: 2,000 yen; assistant 1,000 yen). An aerial photo of Yokohama National University in 2019 shows a green campus (Fig. 14).

Growth data in 1988 and 1993 show the pattern of growth (Miyawaki \& Fujiwara 1988; Fujiwara \& al. 1993) (Fig. 15). Green shows area UB-1, planted in 1976; blue shows area UB-2, planted on a slope in 1979; and brown shows area UB-3, planted on flat ground in 1979. The three year difference in age already showed big growth differences due to the dense plantation (Fig. 16).

UB-1 is flat topography, UB-2 is sloping and UB-3 is flat. The planting density was also different: UB-1 is $1.5 / \mathrm{m}^{2}$, UB-2 is $2.0 / \mathrm{m}^{2}$ and UB-3 is $1.0 / \mathrm{m}^{2}$. The UB-3 site does not have good drainage. From these results one can conclude that: 1 . Dense plantation (more than $1.5 / \mathrm{m}^{2}$ ) shows a better growth rate; 2. Plantation on sloping ground also shows a better growth rate; 3 . Drainage is an important key for good growth; and 4. Cinnamomum camphora has good growth rate in height and diameter both, but it is not native in Japan. Machilus has good growth rate for diameter, but its height is less than for Cinnamomum camphora. The diameter of Quercus species increases slowly, but height is similar to the average of Cinnamomum camphora. Quercus species grow slender and increase their diameter afterward. Now it is around 40 years after plantation. Measurement data will be expected. 


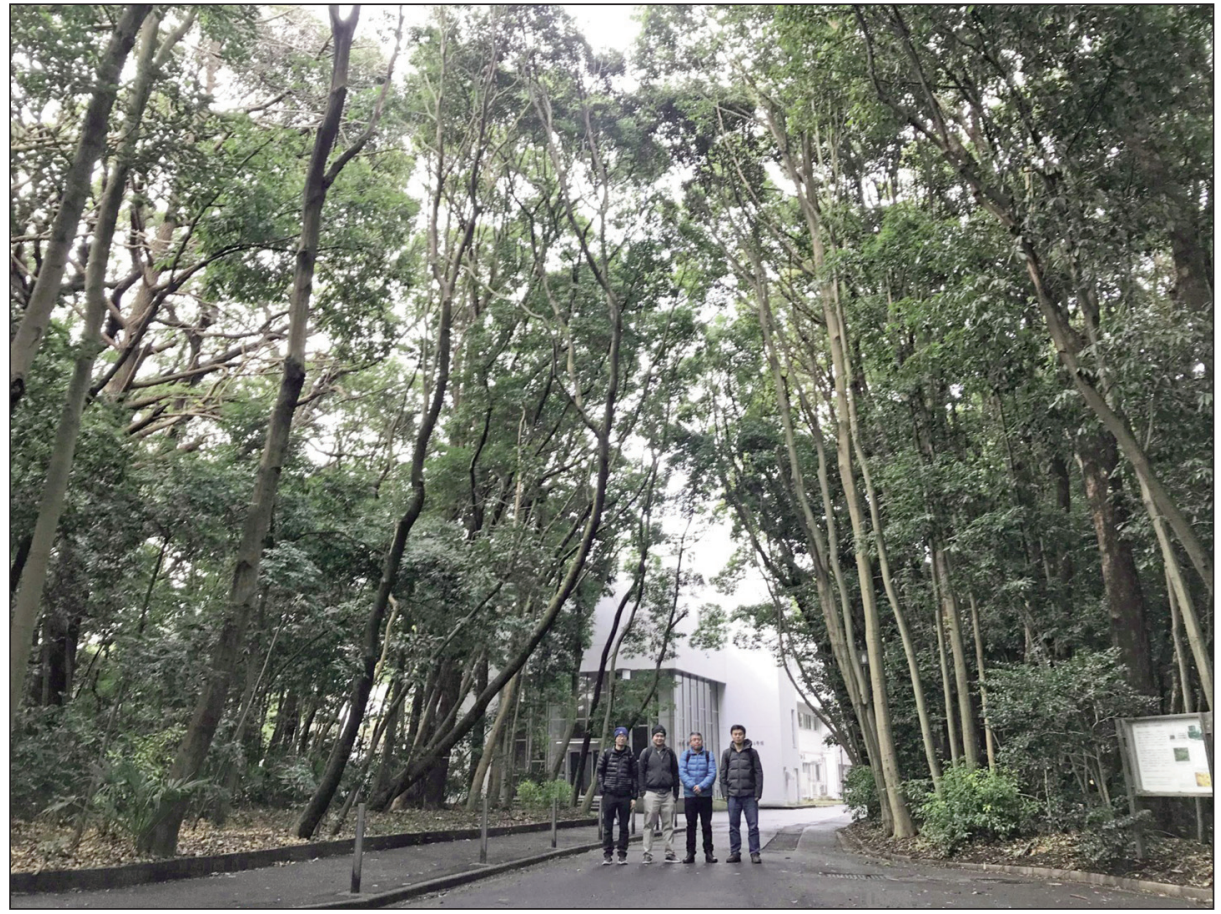

Fig. 13. Environmental protection forest of Fig. 8 in Jan. 2018.

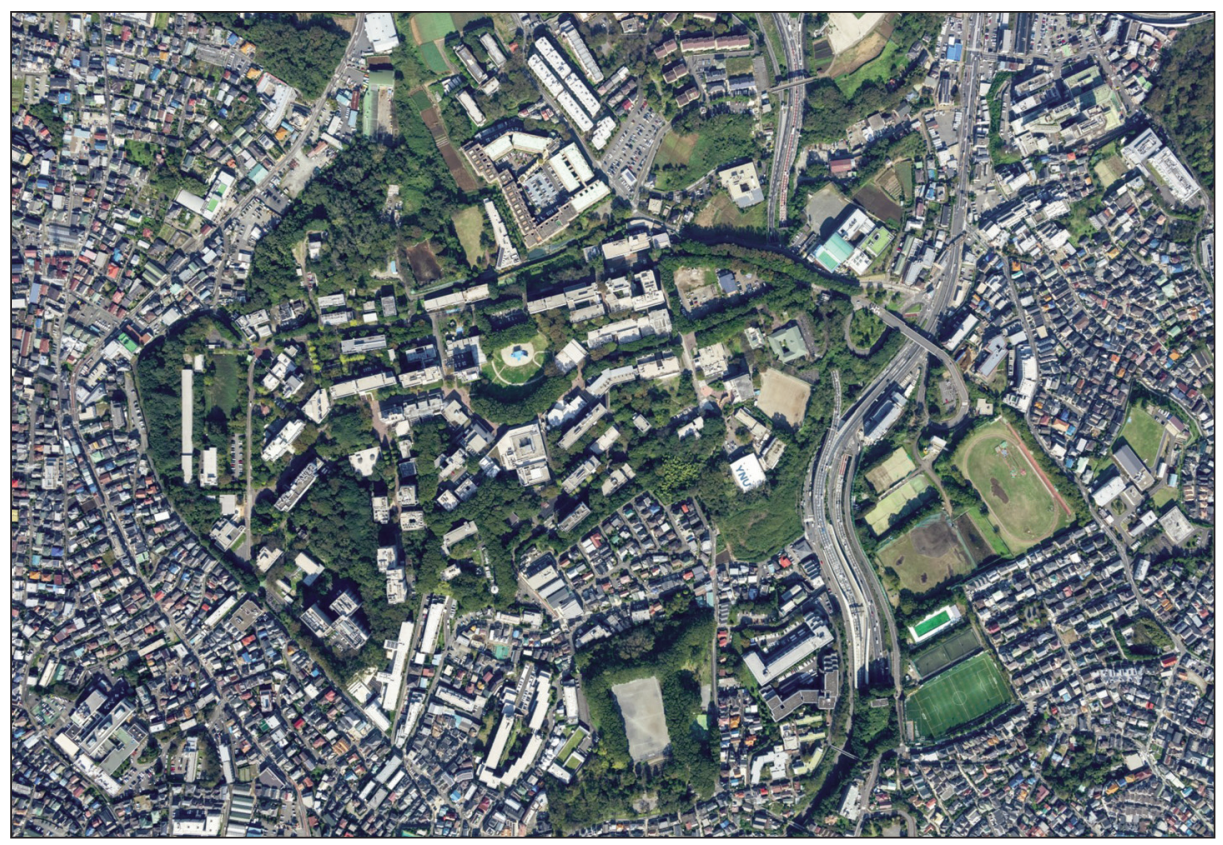

Fig. 14. Aerial photo of Yokohama National University (2019).. 


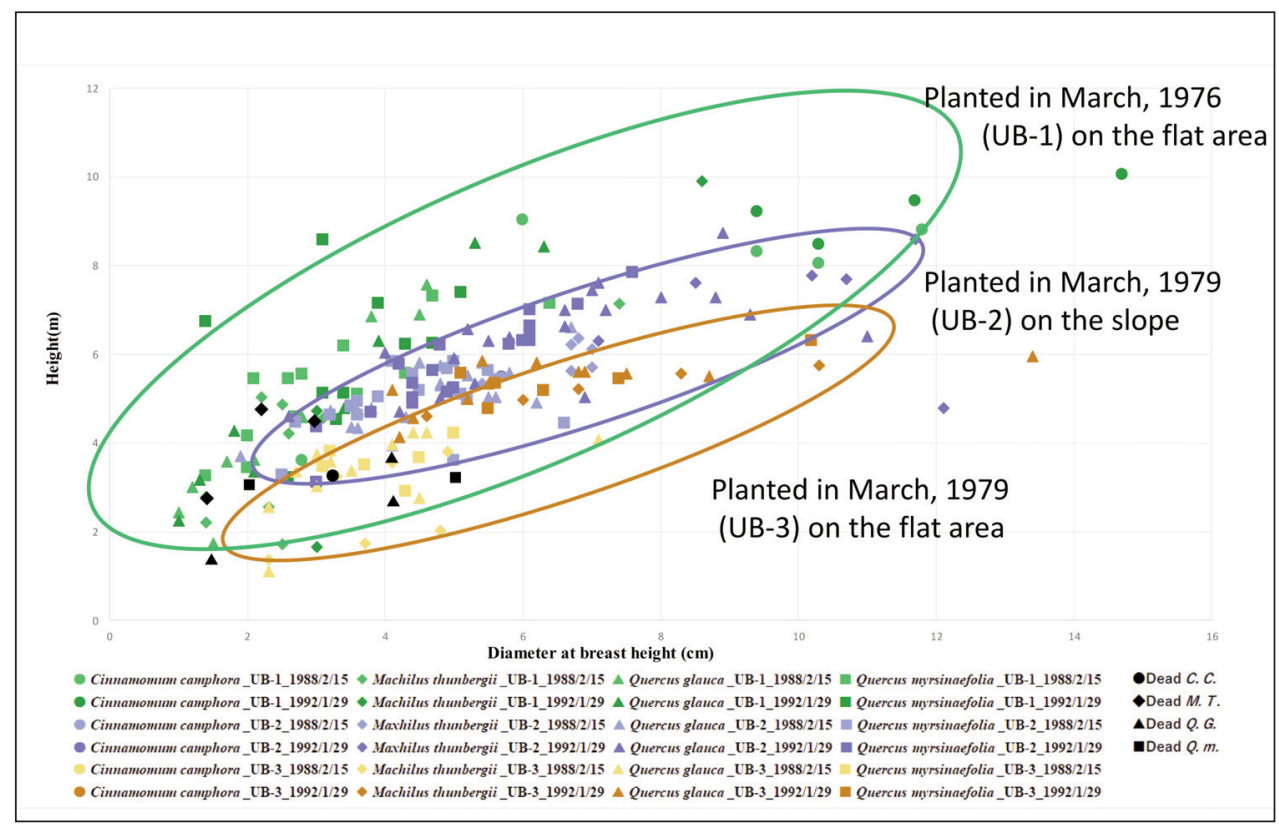

Fig. 15. Relationship of tree height and diameter at breast height in UB-1 3 based on data from 1988 and 1992 (Data from Fujiwara \& al. 1993).

2) Flora of Yokohama National University and Comparison of woody species in seminatural forests and environmental protection forests

The flora of the Tokiwadai campus of Yokohama National University was surveyed before construction in 1968 of the university on the abandoned golf course (Kitagawa \& al. 1968) and reported 274 species. After campus construction, Okuda reported 404 species in 1994, from a four-year survey. In 2000, Tohma and colleagues surveyed the entire campus area and compared the change in the flora since 1968, before and after university construction. Then natural species were 508 species in 108 families, and planted species were 132 species in 65 families (Tohma $\&$ al. 2000). Rare species and red-data species were 54 on the 45.5 ha of campus.

Meiji Jingu and the Institute for Nature Study had natural species occurring, and these have already 100 and 500 years of history. Densely planted forests show good growth rate, but the next target is the return of natural species.

Here the woody species of environmental forests and seminatural forests that are remnants from a golf course (Fig. 11) are compared, and the presence or absence of successors in environmental forests is checked. Successors in the forests of Meiji Jingu and the Institute for Nature Study were reported (Tables 3, 5).

The compositions of the environmental protection forest and old seminatural forests were compared in Table 6 . Forest patches were probably planted when the golf course was constructed in 1922 because old huge Castanopsis occur in lines, mixed with young trees. These are already multi-layered and composed of natural species. 


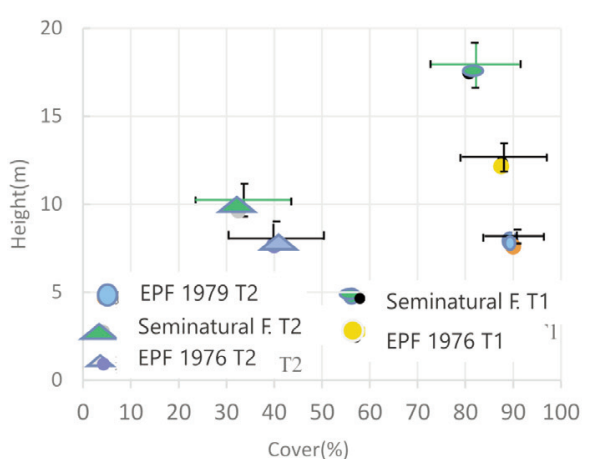

a. Comparison of canopy and subcanopy layers

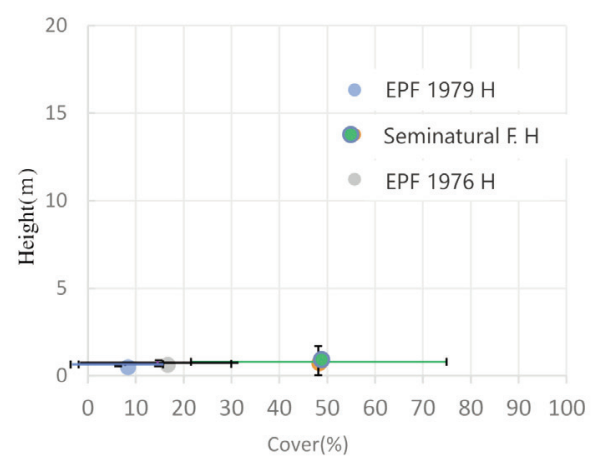

b. Comparison of herb layers

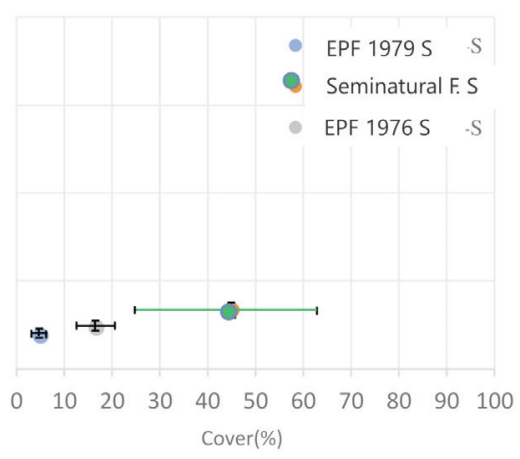

b. Comparison of shrub layers

Fig. 16. Difference of height and cover in different layers of environmental protection forest and relict Castanopis cuspidata var. sieboldii forest at Yokohama National University (Seminatural F.: Seminatural forest; EPF: Environmental protection forest).

The main natural species, i.e. Castanopsis cuspidata var. sieboldii, Ilex crenata, Neolitsea sericea and Osmanthus heterophyllus, are very few or do not occur in the environmental forest at all. Quercus glauca, a planted canopy species, does not occur in remnant Castanopsis forest. Q. glauca occurred in the Meiji Jingu forest but not in the Castanopsis forest at the Institute for Nature Study. On the other hand, Machilus, Q. myrsinaefolia and Ligustrum japonicum can be seen with high frequency.

Developed canopy trees had already had their seeds harvested, and these were germinated and became successors. But the mean species numbers of environmental forest (1927) are half those in seminatural Castanopsis forests $(39,43)$. 
Table 6. Comparison of woody species in various strata of a relict forest (Castanopsis cuspidata var. sieboldii) and restored forests (environmental protection forests) at Yokohama National University and in 1992 (Data from Fujiwara \& al. 1993).

\begin{tabular}{|c|c|c|c|c|c|c|}
\hline \multicolumn{2}{|l|}{ Forest type } & \multicolumn{2}{|c|}{ Seminatural forest } & \multicolumn{3}{|c|}{ Environmental protection fores } \\
\hline & 1 & 2 & 3 & 4 & 5 \\
\hline \multicolumn{2}{|l|}{ Number of relevés } & 4 & 2 & 3 & 5 & 3 \\
\hline \multicolumn{2}{|l|}{ Mean total number of species } & 43 & 39 & 19 & 20 & 27 \\
\hline \multicolumn{2}{|l|}{ Number of EG-BL forest species } & 24 & 21 & 7 & 12 & 15 \\
\hline Species names of woody plants & Stratum & & & & & \\
\hline \multicolumn{7}{|l|}{ Differential woody species: } \\
\hline \multirow{4}{*}{ Castanopsis cuspidata var. sieboldii } & T1 & $4(4-5)$ & $2(4-5)$ & & $\mathrm{I}(1-1)$ & \\
\hline & T2 & $4(1-3)$ & $1(2)$ & $1(2-2)$ & & \\
\hline & $\mathrm{S}$ & $4(+-2)$ & & & $\mathrm{I}(+)$ & \\
\hline & $\mathrm{H}$ & $3(+)$ & $1(+)$ & & & \\
\hline \multirow{2}{*}{ Ilex crenata } & $\mathrm{S}$ & $2(+)$ & $1(+)$ & & & \\
\hline & $\mathrm{H}$ & $3(+)$ & $2(+)$ & & & $1(+)$ \\
\hline \multirow{3}{*}{ Neolitsea sericea } & T2 & $1(+)$ & 1(1) & & & \\
\hline & $\mathrm{S}$ & $3(+)$ & $2(1)$ & & $\mathrm{I}(+)$ & \\
\hline & $\mathrm{H}$ & & $2(+)$ & & & \\
\hline Osmanthus heterophyllus & $\mathrm{H}$ & $3(+)$ & & & & \\
\hline \multirow{2}{*}{ Callicarpa japonica } & $\mathrm{S}$ & $3(+)$ & $1(+)$ & & & \\
\hline & $\mathrm{H}$ & & $1(+)$ & & & \\
\hline \multirow{2}{*}{ Thea sinensis } & $\mathrm{S}$ & & $2(+-1)$ & & & \\
\hline & $\mathrm{H}$ & & $1(1)$ & & & \\
\hline \multirow{3}{*}{ Acer palmatum* } & $\mathrm{T} 2$ & & 1(1) & & & \\
\hline & $\mathrm{S}$ & & $1(2)$ & & & \\
\hline & $\mathrm{H}$ & & $1(+)$ & & & \\
\hline \multirow{4}{*}{ Quercus glauca } & T1 & & & & $\mathrm{II}(1-2)$ & 1(1) \\
\hline & T2 & & & $3(2-3)$ & IV(1-3) & $1(1)$ \\
\hline & $\mathrm{S}$ & & & & $\mathrm{III}(+-1)$ & 1(1) \\
\hline & $\mathrm{H}$ & & & $1(+)$ & $\mathrm{II}(+)$ & \\
\hline \multirow{4}{*}{ Cinnamoтum camphora } & T1 & & & & $\mathrm{II}(3-4)$ & $2(2-3)$ \\
\hline & T2 & & & $2(2-3)$ & $\mathrm{II}(1-2)$ & $1(4)$ \\
\hline & $\mathrm{S}$ & $2(+-1)$ & $1(+)$ & $2(+)$ & $\mathrm{I}(+)$ & $1(+)$ \\
\hline & $\mathrm{H}$ & & $1(+)$ & & $\mathrm{I}(1-1)$ & \\
\hline \multirow{4}{*}{ Machilus thunbergii } & T1 & & $1(2)$ & & IV(1-3) & $2(1-2)$ \\
\hline & T2 & & & $2(2-4)$ & IV $(+-4)$ & $2(2)$ \\
\hline & $\mathrm{S}$ & $1(+)$ & $1(+)$ & $2(+)$ & $\mathrm{III}(+-2)$ & $2(+-1)$ \\
\hline & $\mathrm{H}$ & $1(+)$ & & & $\mathrm{II}(+)$ & $1(+)$ \\
\hline \multirow{4}{*}{ Quercus myrsinaefolia } & T1 & & & & III (1-2) & $2(2-4)$ \\
\hline & $\mathrm{T} 2$ & & 1(1) & $2(2-4)$ & $\mathrm{III}(+-3)$ & $2(1)$ \\
\hline & $\mathrm{S}$ & $1(+)$ & $1(+)$ & & $\mathrm{II}(+-1)$ & $1(+)$ \\
\hline & $\mathrm{H}$ & $1(+)$ & $1(+)$ & $1(+)$ & $\mathrm{III}(+)$ & $3(+)$ \\
\hline \multirow{2}{*}{ Pittosporum tobira* } & $\mathrm{S}$ & & & & $\mathrm{IIII}(+)$ & $1(+)$ \\
\hline & $\mathrm{H}$ & $1(+)$ & & $1(+)$ & $\mathrm{I}(+)$ & $1(+)$ \\
\hline \multirow{2}{*}{ Ligustrum japonicum } & $\mathrm{S}$ & $1(1)$ & $2(+-1)$ & & $\mathrm{I}(+)$ & $1(+)$ \\
\hline & $\mathrm{H}$ & $1(+)$ & & & $\mathrm{IV}(+)$ & $3(+)$ \\
\hline Ligustrum lucidum* & $\mathrm{S}$ & & & & $\mathrm{I}(+)$ & $1(+)$ \\
\hline & $\mathrm{H}$ & & & & $\mathrm{I}(+)$ & \\
\hline Robinia pseudoacacia* & $\mathrm{H}$ & & & & $\mathrm{II}(+)$ & $1(+)$ \\
\hline Trachucarnus fortunei* & $\mathrm{S}$ & $2(+)$ & $2(+-1)$ & & & \\
\hline Tracnycarpus fortunet" & $\mathrm{H}$ & $2(+)$ & $2(+-1)$ & & $\mathrm{V}(+)$ & $3(+-1)$ \\
\hline Ardisia crenata & $\mathrm{H}$ & $4(+-1)$ & & & & $2(+)$ \\
\hline Camellia ianonica & $\mathrm{S}$ & $1(+)$ & & & & $2(+)$ \\
\hline Cameilia japonica & $\mathrm{H}$ & & & & & $1(+)$ \\
\hline
\end{tabular}


Table 6. continued.

\begin{tabular}{|c|c|c|c|c|c|c|}
\hline Camellia sasanqua & $\mathrm{H}$ & & $1(+)$ & & & $1(+)$ \\
\hline \multirow{4}{*}{ Aphananthe aspera } & $\mathrm{T} 1$ & & 1(1) & & & \\
\hline & $\mathrm{T} 2$ & 1(1) & & & & \\
\hline & $\mathrm{S}$ & $1(1)$ & & & & $1(+)$ \\
\hline & $\mathrm{H}$ & & & & & $2(+)$ \\
\hline \multicolumn{7}{|l|}{ Evergreen woody species: } \\
\hline \multirow{2}{*}{ Auсиьа japonica } & $\mathrm{S}$ & $4(1-2)$ & $2(2)$ & & & 1(1) \\
\hline & $\mathrm{H}$ & $3(+-1)$ & $1(+)$ & $1(+)$ & $\mathrm{IV}(+)$ & $1(+)$ \\
\hline \multirow{2}{*}{ Euonymus japonicus } & $\mathrm{S}$ & $1(1)$ & $1(+)$ & & $\mathrm{I}(+)$ & $1(+)$ \\
\hline & $\mathrm{H}$ & $2(+)$ & & & $\mathrm{II}(+)$ & $2(+)$ \\
\hline \multirow{2}{*}{ Eurya japonica } & $\mathrm{T} 2$ & $3(+-1)$ & & & & \\
\hline & $\mathrm{S}$ & $4(+-1)$ & & & & $1(+-1)$ \\
\hline \multirow{2}{*}{ Fatsia japonica } & $\mathrm{S}$ & $4(1-2)$ & & & $\mathrm{I}(+)$ & \\
\hline & $\mathrm{H}$ & $4(1)$ & $2(+)$ & $1(+)$ & $\mathrm{III}(+)$ & $2(+)$ \\
\hline Viburnum awabuki* & $\mathrm{H}$ & $1(+)$ & & & $\mathrm{I}(+)$ & \\
\hline \multirow{2}{*}{ Pyracantha angustifolia* } & $\mathrm{S}$ & & & & $\mathrm{I}(+)$ & \\
\hline & $\mathrm{H}$ & & & & & $1(+)$ \\
\hline Pinus densiflora & $\mathrm{S}$ & $1(2)$ & & & $\mathrm{I}(+)$ & \\
\hline Ilex integra & $\mathrm{S}$ & $1(+)$ & & & & \\
\hline Dendropanax trifidus & $\mathrm{H}$ & $1(+)$ & & & & \\
\hline Cinnamomum japonicum & $\mathrm{S}$ & $1(+)$ & & & & \\
\hline \multirow{2}{*}{ Ternstroemia gymnanthera* } & $\mathrm{S}$ & & & & $\mathrm{I}(+)$ & \\
\hline & $\mathrm{H}$ & & & & $\mathrm{I}(+)$ & \\
\hline Rhaphiolepis umbellata var. integerrima* & $\mathrm{H}$ & & & & $\mathrm{I}(+)$ & \\
\hline \multicolumn{7}{|l|}{\begin{tabular}{|l|} 
Deciduous woody species: \\
\end{tabular}} \\
\hline \multirow{3}{*}{ Zelkova serrata } & $\mathrm{T} 2$ & $1(+)$ & & & & \\
\hline & $\mathrm{S}$ & $3(+)$ & & & $\mathrm{II}(+)$ & \\
\hline & $\mathrm{H}$ & $1(+)$ & $1(+)$ & $1(+)$ & $\mathrm{III}(+)$ & $3(+)$ \\
\hline \multirow{3}{*}{ Celtis sinensis var. japonica } & T1 & & $1(2)$ & & & \\
\hline & $\mathrm{T} 2$ & $1(1)$ & & & $\mathrm{I}(+)$ & \\
\hline & $\mathrm{S}$ & $4(+-2)$ & & $1(+)$ & $\mathrm{II}(+)$ & $2(+)$ \\
\hline Magnolia kobus & $\mathrm{H}$ & & & & $\mathrm{I}(+)$ & $1(+)$ \\
\hline \multirow{2}{*}{ Morus bombycis } & $\mathrm{S}$ & $3(+)$ & & $1(+)$ & $\mathrm{III}(+)$ & $3(+)$ \\
\hline & $\mathrm{H}$ & & $1(+)$ & $1(+)$ & $\mathrm{I}(+)$ & \\
\hline \multirow{4}{*}{ Cornus controversa } & $\mathrm{T} 1$ & & $1(1)$ & & & \\
\hline & $\mathrm{T} 2$ & $3(1-2)$ & & & & 1(2) \\
\hline & S & $1(1)$ & $1(1)$ & & & $1(+)$ \\
\hline & $\mathrm{H}$ & & & $1(+)$ & & \\
\hline Prunus grayana & $\mathrm{H}$ & $1(+)$ & & $1(+)$ & & $1(+)$ \\
\hline \multirow{2}{*}{ Idesia polycarpa } & T1 & $1(1)$ & & & & \\
\hline & $\mathrm{T} 2$ & $1(1)$ & & & & \\
\hline \multirow{2}{*}{ Pourthiaea villosa var. laevis } & $\mathrm{S}$ & $1(+)$ & & & & \\
\hline & $\mathrm{H}$ & & $1(+)$ & & & \\
\hline \multirow{2}{*}{ Viburnum dilatatum } & $\mathrm{S}$ & $4(+)$ & & & & \\
\hline & $\mathrm{H}$ & $1(+)$ & $1(+)$ & & & \\
\hline \multirow{2}{*}{ Cornus brachypoda } & $\mathrm{T} 2$ & $1(1)$ & & & & \\
\hline & $\mathrm{H}$ & $1(+)$ & & & & \\
\hline Ginkgo biloba* & $\mathrm{H}$ & & & $1(+)$ & & $1(+)$ \\
\hline
\end{tabular}


Sites planted in 1979 still had low mean numbers of total species. Harada and Hayashi surveyed environmental forest species in 2017 (Harada \& Hayashi 2019) and found only one species increased. Sample numbers were not reported, so this cannot be discussed here. It is discussed in the Discussion and Conclusion section.

Both forest types have Trachycarpus fortunei, Aucuba japonica and Fatsia japonica relatively frequently. These species are dispersed easily by birds from the surroundings.

Forest height and cover of remnant Castanopsis forests (seminatural forest) and environmental forests were compared in Fig. 16. The canopy layer of seminatural forests is tall, but environmental forest planted in 1976 is taller than the subcanopy layer of seminatural forests. Canopy coverage widths of seminatural and environmental protection forests are similar with that of the subcanopy layer. The subcanopy layer of seminatural forest has lower coverage than does the environmental forest planted in 1976.

The cover of the shrub layer of seminatural forests has a wider range, but the cover of environmental forests has a narrow range. This means that shrub-layer cover has not yet developed fully. The herb layer of seminatural forests also has a wider range and high coverage. It means that the herb layer of seminatural forest is developed and that of environmental forests is not yet developed (Fig. 16).

\section{Discussion and Conclusion}

The area of the Meiji Jingu forest is 70 ha, and it is the third-largest green area in the Tokyo metropolitan area. The area of the Institute for Nature Study is 18.9 ha (Hamano \& al. 2013). The Meiji Jingu forest (evergreen broad-leaved forest) covers most of the area, except precincts and landscaping areas. The Institute for Nature Study has narrow Castanopsis forest on an embankment, secondary deciduous Q. serrata forest and Cornus controversa pioneer forest, and a relict of Japanese garden with pond and wetland. Successsors of Castanopsis forests on the embankment were discussed. The area of Yokohama National University is 45.5 ha, which is only half that of the Meiji Jingu forest. The relict forest from the old golf course and the forest restored by the new ecological method were compared. These three forest areas have different histories, but these are important models for restoration of natural forests.

The created forest of Meiji Jingu has 100 years of planning for forest development based on succession. It has succeeded with excellent basic planning as a scheme, a huge plantation operation, and detailed management planning for the future. The Institute for Nature Study has a long history since the Muromachi Period (1336-1573) and has been protected under several environmental changes (Institute for Nature Study of National Museum of Nature and Science 1999, http://www.ins.kahaku.go.jp/english/about/ history /index.html).

The plantation method by Hongo in 1923 (Fig. 8) succeeded in developing natural forest in 100 years. It is characterized by: 1) Expected succession to evergreen broad-leaved forest in 100 years; 2) Selection of species from conifer to evergreen broad-leaved species for growing to climax forest after succession; and 3) Guidelines for maintenance, such as prohibiting weeding and the collection of dropped leaves. Cleaning of dropped leaves should be done around buildings, on roads or in the garden, but not in the forests. Cleaning and weeding in the forest cause a decline in soil fertility and lead to forest impoverishment. 
When weeds grow higher than new saplings, weeding is necessary - but only for a few years after planting. This maintenance guideline was used later by Prof. Miyawaki who developed the "Miyawaki method" for restoration of natural forest in shorter time. The forests at the Institute for Nature Study had a long history of protection after creation of the Japanese garden. There were also several other disturbances, including the gunpowder magazine, under the control of the Naval Ministry and Army Ministry in 1917; and export of trees for transplanting in the Meiji Jingu forest in 1973. After such history, the site passed to the Ministry of Education in 1949, whereupon it was designated a "national monument and historical landmark" and opened to the public as a national natural-education park. Then it obtained its current status as the Institute for Nature Study of the National Museum of Nature and Science in 1962. Many scientific studies have been done and recorded.

The environmental protection forests of Yokohama National University were planted based on the Miyawaki theory: 1) plant potted seedlings (30-80 cm height) with well-developed root systems, of canopy species of the potential natural forest (Tüxen 1958); 2) plant densely (1-3 individuals per square meter); 3. mix the plantation randomly; and 4. no need for management after three years.

The three models for forest creation were compared based on flora and development. The forest around the Meiji Jingu and the forest at the Institute for Nature Study have rich flora and biodiversity of fauna, based on areas, history and various landscaping as pond, garden, grassland and wetland.

Yokohama National University has mainly buildings and surrounding spaces, where environmental protection forest and landscaping plantation were begun in 1976.

The flora of the Meiji Jingu forest (Cinnamomum camphora-Castanopsis cuspidata var. sieboldii community) decreased from 166 species to 135 species over the last 40 years (Miyawaki \& al. 1980; Okutomi \& al. 2013). The species of evergreen broad-leaved forest increased from 38 to 45 species (Matsuzaki \& Okutomi 2014), but these species included species that had escaped from gardens. Real natural species will be 36, as based on Fujiwara (1981, 1986). The evergreen 36-40 species of evergreen broad-leaved forest are optimum in the Kanto region. Castanopsis forest at the Institute for Nature Study (Okuda \& Miyawaki 1966) has 33 species of the evergreen broad-leaved forest (Camellietea japonicae species in Kanto region). The forest of Miyazaki Jingu in Miyazaki Prefecture in Kyushu has a plantation history (Hattori \& al. 2010) similar to that of Meiji Jingu. It also has 100 years of history after plantation. The big difference was the plantation method, with ca 30,000 trees of Cinnamomum camphora, Pinus spp., Chamaecyparis obtusa, etc. in 1907, but it looked like a "scattered" forest (Kuroki 2007 in Hattori \& al. 2010).

Hattori \& al. (2010) compared species richness to that of other lucidophyllous forests (primeval, natural and secondary forests), but the species richness was not as much as in primeval and natural forests because the species numbers and composition ratio of epiphytes and terrestrial pterophytes are low. These numbers are similar to those of secondary lucidophyllous forests (Hattori \& Ishida 2000). Epiphytes and terrestrial pterophytes occur in moist environments. The Miyazaki Jingu Shrine has a forest of ca 15 ha on an alluvial area. Primeval and natural forests remain on hilly or low mountain areas. Miyazaki shrine cannot hold moisture like mountain areas. The forest of Miyazaki Jingu Shrine is multi-layered, with canopy spread and endangered species. When we expect more terrestrial ferns and epiphytes, though, edge community is required for closed forest. 
The environmental protection forests of Yokohama National University have shorter history than do the forests of Meiji Jingu and the Institute for Nature Study. The species native to evergreen broad-leaved forests of these three places are roughly similar except for species that have escaped from gardens. Kuboyama surveyed forests around shrines and temples in Kanto and found them to have been invaded by ornamental and garden plants within 30 years (Kuboyama \& Fujiwara 2008). The forests were 207 plots in 1970, but 69 plots disappeared, changing to Japanese cedar plantation, secondary forests in gaps, and to cemeteries. The number of species of evergreen broad-leaved forest and of ornamental and garden species increased, while species of secondary forests decreased. The Kanto region has the smallest number of species of evergreen broad-leaved forest in Japan, since it is near the northern limit for many such species. Environmental forests were investigated in the littoral area around the Seto Inland Sea and in Fukui on the Japan Sea coast (Hattori \& al. 2001). People planted natural species at 9-18 species per $100 \mathrm{~m}^{2}$ on these environmental forest sites. The authors compared with primeval forest in Kagoshima, Kyushu, and included all newcomers and total species number as their measure for species richness. This is not reasonable for restoration of evergreen broad-leaved forests because weeds, secondary species and pioneer species are indicators of forest disturbance. Later authors changed the focus to natural species in Miyazaki, Kyushu (Ishida \& Hattori 2005). The species composing evergreen broad-leaved forests in Miyazaki are very many, especially terrestrial ferns and epiphytes, because of high temperature and moisture occurring on the complex topography. These species are different from the coastal area of the Seto Inland Sea and the Kanto region. Anyway, the authors ascertained that seed dispersal is largely by birds. Isolated forests were located more than $500 \mathrm{~m}$ from resource forests.

The species composing the evergreen broad-leaved forests of these three types varied according to width, forest history, and area. Isolated forests required bird food, water and nest areas in the forests.

Harada and Hayashi (2019) gave a hypothesis that thickly deposited fallen leaves on the forest floor hinder the recovery of the species composition in environmental protection forests. This hypothesis makes a paradox for maintenance, especially the suggestion by Hongo (1923) to prohibit cleaning dropped leaves. When we focus on natural forest, we should let the forest regulate itself.

This discussion suggests that we will be better off to think of forest restoration as plantation with many species, especially including bird-dispersed species, helped initially by creating good soil at the plantation sites. We would like to continue watching these forests and increase the restoration of natural forests in a better way.

\section{Dedication and Acknowledgements}

This paper is dedicated to Prof. Sandro Pignatti for his $90^{\text {th }}$ birthday celebration. Prof. Pignatti required me to write for restoration of natural forest many years ago. Finally, I got an idea to compare the old restored forests and new ecological technology forest for him. I say thanks for giving ideas always and please lead us for a long time more. I also would like to thank Prof. Dr. Shin-ichi Suzuki, Tokyo University of Agriculture, who provided me huge reports on the Meiji Jingu forest in 2013. 
It is difficult to get this information nowadays. I am grateful also to Mrs. Akiko Shimoda, who provided me lots of research reports on the Institute for Nature Study. I thank Mrs. Masami Sugita and Mrs. Rina Sakamoto who made the tables, and Prof. Dr. You Hai-Mei, Jiangsu Normal University, who made graphs. Finally I thank Prof. Elgene Box for editing the English and always encouraging me to finish this paper.

\section{References}

Fujiwara, K. 1981: Phytosociological investigation of the evergreen broad-leaved forest of Japan-1. - Bull. Inst. Environ. Sci. Technol., Yokohama Nat. Univ. 7(1): 67-135 [in Japanese with English synopsis].

— 1986 (1): The evergreen broad-leaved forest. - Pp. 129-145 in: Miyawaki, A. (ed.), Vegetation of Japan, 7. - Tokyo [in Japanese].

—, Hayashi, H. \& Miyawaki, A. 1993: Restoration of natural environment by creation of environmental protection forests in urban areas. Growth and development of environmental protection forests on the Yokohama National University Campus. Second report. - Bull. Inst. Environ. Sci. Technol., Yokohama Nat. Univ. 19: 51-60.

Hamano, C. 2013: Spermatophyta of the Shrine Forest of Meiji Jingu. - Pp. 69-87 in: Meiji Jingu Precincts Comprehensive Investigation Committee (ed.), Meiji Jingu Precincts Comprehensive Survey Report. - Tokyo [in Japanese with English abstract].

-, Nakatake, Y. \& Okisawa, K. 2013: Tree measurement at the Shrine forest of Meiji Jingu. - Pp. 13-28 in: Meiji Jingu Precincts Comprehensive Investigation Committee (ed.), Meiji Jingu Precincts Comprehensive Survey Report. - Tokyo [in Japanese].

Hamao, S., Matsuura, K. \& Hagiwara, S. 2013: Green space in the big urban: The forest of the Institute for Nature Study. - Pp. xvii-xxii in: Hamao, S. \& Matsuura, K. (eds), Biodiversity and environment of the Institute for Nature Study. - Tokyo [in Japanese].

Harada, H. \& Hayashi, H. 2019: Hypothesis that thickly deposited fallen leaves on the forest floor are hindering the recovery of the species composition of the environmental protection forest. - Pp. 24-26 in: JISE Report No. 2 [in Japanese].

Hattori, T. \& Ishida, H. 2000: Relationship between species diversity, species composition and forest area of fragmented lucidophyllous forests in central Miyazaki Prefecture. - Japanese J. Ecol. 50: 221-234 [in Japanese with English summary].

—, Iwakiri, K., Minamiyama, N., Kuroki, S. \& Kuroda, A. 2010: Structure, species richness, and species composition of the shrine forest in Miyazaki-Jingu, Miyazaki Prefecture. - Jap. Jour. Conserv. Ecol. 15: 47-59 [in Japanese with English abstract].

—, Ono, Y., Kaji, K., Ishida, H., Suzuki, T. \& Iwasaki, M. 2001: Relationship between source in plant species follow and species richness in the lucidophyllous artificial forests on the littoral districts. - J. JILA 64(5): 545-548 [in Japanese with English summary].

Hongo, T. 1923: Forest Garden planning of Meiji Jingu shrine. - Pp. 447-726 in: Meiji Jingu 2004. Meiji Jingu Series (Meiji Jingu Sousho) 13. Construction edition-2. 731 pp. - Tokyo [in Japanese].

Honda, M., Yano, T. \& Kato, N. 1980: Seed plants. - Pp. 208-228 in: Meiji Jingu Precincts Comprehensive Survey Report. - Tokyo [in Japanese].

Ishida, H., Hattori, T. \& Hashimoto, Y. 2005: Comparison of species composition and richness among primeval, natural, and secondary lucidophyllous forests in southeastern Kyushu, Japan. - Veg. Sci. 22: 71-86.

Ishigami, K. 1980: Tree survey report. - Pp. 1-205 in: Meiji Jingu Precincts Comprehensive Survey Report. - Tokyo [in Japanese]. 
Kitagawa, M., Miyawaki, A. \& Kawamura, Y. 1968: Vegetation and ecological diagnosis in the integrated site of Yokohama National University. - Pp. 1-13 in: Newsletter of integrated campus of Yokohama National University. - Yokohama [in Japanese].

Kuboyama, E. \& Fujiwara, K. 2008: Changes in species composition in lucidophyllous forests around Shinto shrines and temples in Kanto, Japan. - Papers Environ. Inform. Sci. 22: 109-174 [in Japanese with English abstract].

Matuzaki, Y. \& Okutomi, K. 2014: Forest vegetation of Meiji Jingu. - Pp. 12-14 in: Green Age 2014/7. - Tokyo [in Japanese].

Ministry of Home Affairs Shrine Bureau (Naimushou Jinjakyoku) 1930: Construction document of Meiji Jingu (Meiji Jingu Souei-shi). - Pp. 1-445 in: Meiji Jingu Series (Meiji Jingu Sousho) 13. Construction edition-2. 731 pp. - Tokyo [in Japanese].

Miyawaki, A. 1979: Environmental improvement plan. - Pp. 32-35 in: 30th Anniversary of Yokohama National University: 30 years of history. - Yokohama [in Japanese].

— \& Fujiwara, K. 1988: Restoration of natural environmental protection forests in urban areas. Growth and development of environmental protection forests on the Yokohama National University campus. - Bull. Inst. Environ. Sci. Technol., Yokohama Nat. Univ. 15: 95-102.

_, — \& Ozawa, M. 1993: Native forests by native trees. Restoration of indigenous forest ecosystem. (Reconstruction of environmental protection forest by Prof. Miyawaki's method). - Bull. Inst. Environ. Sci. Technol., Yokohama Nat. Univ. 19: 73-107 [in Japanese and English].

—, Okuda, S. \& Inoue, K. 1980: Pflanzensoziologische Untersuchungen in den Wäldern des MeijiSchreins in Tokyo. - Pp. 269-333 in: Meiji Jingu Precincts Comprehensive Investigation Committee (ed.), Meiji Jingu Precincts Comprehensive Survey Report. - Tokyo [in Japanese with German summary].

—, Sasaki, Y., Okuda, S., Harada, H., Fujiwara, K., Suzuki, K. \& Hotta, K. 1974: Phytosociological studies on creation of environmental protection forests around schools. - Based on field surveyes at 158 schools throughout Japan. - 116 pp. Contrib. of Dept. Veget. Scie., Inst. Envir. Scie. Tech., Yokohama National Univ. No. 12 [in Japanese].

—, Tohma, H., Fujiwara, K., Inoue, K., Furuya, M., Sasaki, Y., Harada, H., Ohno, K. \& Suzuki, K. 1972: Vegetation der Stadt Yokohama - Eine pflanzensoziologische Studie fuer den Umbeltschut und die Dchaffung einer vegetationsreichen Stadt. - Yokohama [in Japanese with German summary].

Okuda, S. 1969: Die Vegetation des Naturrests in der Stadt Tokyo 1. - Misc. Reports Natl. Park Nat. Stu. 1: 19-24 [in Japanese with German summary].

— 1970: Über die Vegetation der Umgebung des Naturparks für Naturstudien im südwestlichen Teil der Stadt Tokyo, Die Vegetation der Naturreste in der Stadt Tokyo 2. - Misc. Reports Natl. Park Nat. Stud. 2: 9-15 [in Japanese with German summary].

- 1972: Growth of old huge Shii-trees (Castanopsis cuspidata var. sieboldii) and their conservation in the National Park for Nature Study. - Pp. 1-16 in: Misc. Reports Natl. Park Nat. Stud. 3 [in Japanese with English summary].

- 1980: Die Pflanzengesellschaften des Naturparks für Naturstudien in Tokyo. - Ihre Entwicklungen und Veränderungen in den letzten 15 Jahren. - Pp. 5-22 in: Misc. Reports Natl. Park Nat. Stud. 11 [in Japanese with German summary].

- 1994: Flora of Yokohama National University, Tokiwadai campus. - Bull. Inst. Environ. Sci. Technol., Yokohama Nat. Univ. 20: 147-159 [in Japanese and English synopsis].

- 2001: Vegetation Map of the Institute for Nature Study. - Rep. Inst. Nat. Stu. 33: 71-79 [in Japanese].

- 2013: Vegetation and flora of the Institute for Nature Study. Laurel forest alive in the big city. - Pp. 2-12 in: Hamao, S. \& Matsuura, K. (eds), Biodiversity and environment of the Institute for Nature Study. - Tokyo [in Japanese]. 
— \& Miyawaki, A. 1966: Reale Vegetationskarte des Staatlichen Naturparks für Naturstudien in Tokyo. - Pp. 1-14 in: Ecological Studies of Biotic Communities in the National Park for Nature Study. Foundation of Outdoor Nature Museum Supporters Association. - Tokyo [in Japanese with German summary].

Okutomi, K., Matsuzaki, Y. \& Ikeda, H. 2013: Forest vegetation of Meiji Jingu. - Pp. 29-68 in: Second Meiji Jingu Precincts Comprehensive Investigation Committee for 100th anniversary of the enshrined seat (ed.), Report on the 100th anniversary of the enshrined seat in the precincts of the Meiji Jingu Shrine. - Tokyo [in Japanese with English abstract].

—, Okuda, S. Tsujii, S. \& Hoshino, Y. 1987: Studies on the vegetation of Tokyo. 282 pp. - Tokyo [in Japanese with English summary].

The Institute for Nature Study of National Museum of Nature and Science 1999: 50 years history of the Institute for Nature Study. - Tokyo [in Japanese].

Tohma, H., Harada, A. \& Fujiwara, K. 2001: The Flora and distribution of plants in the Tokiwadai campus of the Yokohama National University. - Bull. Inst. Environ. Sci. Technol., Yokohama Nat. Univ. 27: 33-47 [in Japanese with English synopsis].

Tüxen, R. 1958: Die heutige potentielle natürliche Vegetation als Gegenstand der Vegetationskartierung. Berichte zur Deutschen Landeskunde herausgegeben von der Bundesanstalt für Landeskunde. Zentralarchiv für Landeskunde von Deutschland. 2 Heft. pp. 200-225. - Remagen.

Uchida, M. 1992: Chapter 1. The Forest Was Created In This Way-Planning and Background of Construction. - Pp. 27-64 in: Matsui, M., Uchida, M., Tanimoto, T. \& Kitamura, M.: Forest created in a big city-Learn from the forest of Meiji Jingu. - Tokyo [in Japanese].

Uehara, K. 1971: Forest made by people. - Record of construction of Meiji Jingu Forest. 77pp. (republished in 2009. Forest made by people. - Record of construction of Meiji Jingu Forest (forever forest). - Tokyo [in Japanese].

Address of the author:

Kazue Fujiwara,

(Prof. emerita of Yokohama National University)

Yokohama City University, Graduate School in Nanobioscience, Endowed Laboratory for Restoration of Terrestrial Environments, Seto 22-2, Kanazawa-ku, Yokohama City, Kanagawa, 236-0027 Japan. Email: kazue05fujiwara@gmail.com 